\title{
Antonín Dvorák in the Notes of the Traveller Josef Korenský and Czech Society in America in 1893
}

\section{Veronika Vejvodová}

Abstract: The article is based primarily on Josef Kořenskýs travelogue and diary, and in broader historical contexts it reports on Kořenskýs contacts with Antonín Dvořák in Prague in the 1870s and '80s and in New York, where the two men met in late May and early June of 1893 . There is a detailed description of the voyage to America, including the realities of ocean crossings and information about Dvorák's family. There are also introductions of other figures from the circle of Czech artists and intellectuals in New York at the time, such as Alfred Baštýř, who took stereoscopic photographs of the Dvořák family, and the violinist Karel Ondříček. The connections between Kořenskýs journey to America and the Czech patriotic milieu also receive attention.

Key words: Antonín Dvořák, Josef Kořenský, New York, Alfred Baštýř, stereoscopic photography, Czech society in America, 1893, World’s Fair in Chicago, travelogue, diary, Vojta Náprstek

From the existing scholarly literature, we learn very little about contacts between the teacher and traveller Josef Kořenský (1847-1938) and Antonín Dvořák (1841-1904). ${ }^{1}$ Although Kořenský was not in the circle of Dvořák's closest friends, we know that the two were acquainted through Prague's patriotic circles and that they established more intensive contact in New York in late May and the first half of June of 1893. In his diary, ${ }^{2}$ Kořenský recorded the circumstances of these encounters and other details from the journey to New York that he made on board a ship together with the sister of Dvoŕák's wife, Terezie Koutecká, and four of Dvořák's six children. Those notes later served as the basis for writing

This work was financially supported by the Ministry of Culture of the Czech Republic (DKRVO 20192023/23.I.a, National Museum, 00023272).

1) Otakar Šourek wanted to cover the relationship between Kořenský and Dvořák. This can be seen from Kořenský's letter to Šourek dated 23 Oct. 1934, kept at the National Museum - Antonín Dvořák Museum (hereinafter NM-MAD), Otakar Šourek estate, acquisition no. 88/98.

2) The diary is kept at the National Museum - Náprstek Museum of Asian, African, and American Cultures (hereinafter NM-NpM), Sbírkové oddělení-Archiv (Department of Collections, Archives), shelf mark Kořenský $3 / 33$. 
his two-volume travelogue Cesta kolem svèta (Journey around the World). ${ }^{3}$ Neither Kořenskýs diary nor the published travelogue have heretofore been the subject of research by Dvořák experts.

\section{Guests in the Neff home}

Josef Kořenský, a native of Sušno, a village near the city Mladá Boleslav, was a teacher and a traveller who published the experiences from his journeys in travelogues. He was a friend of Emil Holub, whom he had met in the salon of the Náprstek family at their home, a house called "U Halánků", where the intellectual elite of society gathered. Antonín Dvořák apparently went there sporadically as well. Kořenský maintained very close relations with the Náprstek family, and they gave him financial support for his travels. From 1874 to 1938 he worked as a teacher and later as the headmaster of a girls' school in Prague-Smíchov. He went on his travels mostly during school holidays. He was

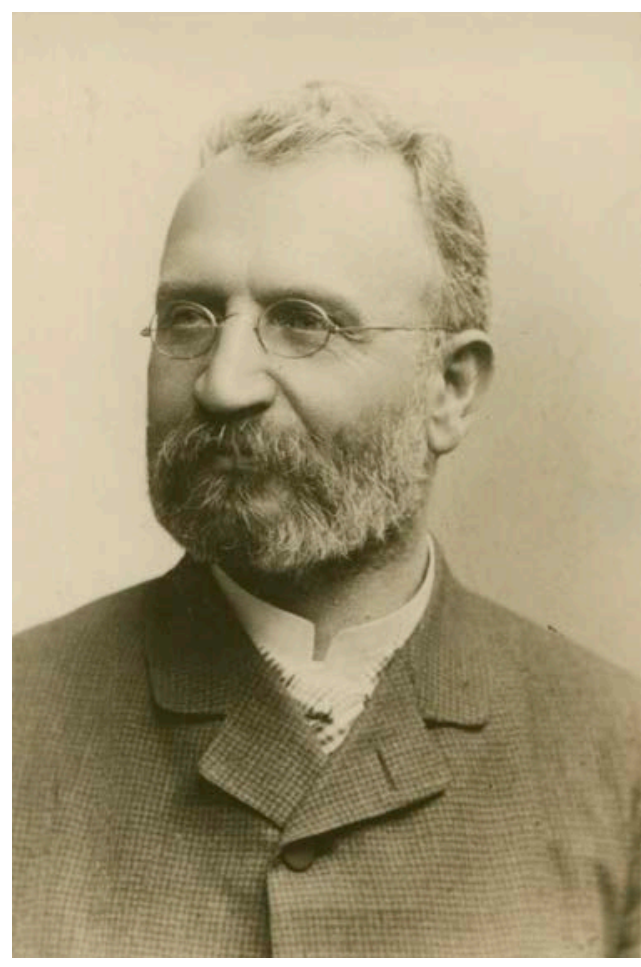

Josef Kořenský (1847-1938)

Portrait, unknown photographer, 1907 / Portrétní fotografie, autor neznámý, 1907

NM-NpM, Kořenský 10/1 most celebrated for his journey around the world, which he undertook together with the landholder Karel Řezníček in 1893.

Josef Kořenský apparently first met Dvořák at the family home of the merchant and patriot Jan Neff. According to Otakar Šourek, the composer was the tutor of the Neff children from 1873 and was also regularly present at their evening social events, ${ }^{4}$ to which a succession of patriots from Prague and Moravia were invited, as well as representatives of other Slavic

3) KOŘENSKÝ, Josef: Cesta kolem světa 1893-94. Díl I. Atlantický oceán, Amerika, Tichý oceán, Ostrovy Havajské, Žaponsko (Journey Around the World 1893-94. Part I. Atlantic Ocean, America, Pacific Ocean, Hawaiian Islands, Japan), J. Otto, Praha [between 1896 and 1902] (hereinafter KOŘENSKÝ I); KOŘENSKÝ, Josef: Cesta kolem světa 1893-94. Díl II. Čína, Malajské souostroví, Cejlon, Indie, Rudé moře, Egypt (Journey Around the World 1893-94. Part II. China, the Malay Archipelago, Ceylon, India, the Red Sea, Egypt), J. Otto, Praha [between 1896 and 1902].

4) ŠOUREK, Otakar: Jan Neff a(nd) Antonín Dvořák, in: Jan Neff 1832-1932, Miloš and Vladimír Neff, Praha 1932, pp. 71-81 (hereinafter ŠOUREK); ŠOUREK, Otakar: Dvořák a Neffovi (Dvořák and the Neffs), in: Z Dvořákovy cesty za slávou. Hrst proslovů a článků (From Dvořák’s Path towards Fame. A Handful of Addresses and Articles), Hudební matice Umělecké besedy (Music Publisher of the Artists' Association), Praha 1949, pp. 41-67, 165-166; ŠOUREK, Otakar: Život a dílo Antonína Dvořáka, část pruní, 1841-1877 (The Life and Work of Antonín Dvořák, part I, 1841-1877), $3^{\text {rd }}$ edition, Státní nakladatelství krásné literatury, hudby a umění (State Publisher for Belles-Lettres, Music, and Art), Praha 1954, pp. 225-227. 
nationalities (mostly Russians and Poles) from the circles of Neff's friends and relatives. ${ }^{5}$ There, Dvořák would certainly have seen Kořenský, who was a regular guest of the Neff family, as is documented in his memoirs.

In his first reminiscence, Kořenský also became the only person to document that it was not only Mr. and Mrs. Neff and their governess Marie Blažková who sang the Moravian Duets, but also the wife of Ladislav Čelakovský, Louisa Čelakovská.

"Ian Neff's second marriage gave him new life, and through the efforts of his exemplary spouse, an enthusiastic patriot, the family began extending hospitality to frequent gatherings of devoted friends. The Moravian Duets of the triumphant Dvorák accompanied by the master himself at the piano lent the dinner parties a festive touch and a joyous mood to all of the numerous listeners. The voices of the two singers, usually Mrs. Marie Neffová and her friend Mrs. Člakovská, wife of the famed botanist, were enchanting, and it was for this reason that the great composer played the accompaniment."

This shows that Kořenský was able to visit the Neff salon at approximately the same time when Dvoŕák was doing so, because at the beginning of the 1874/1875 school year, the youthful Kořenský began working as a specialised teacher at a public school for girls in Prague-Smíchov on Přívozní Street, and having just moved to Prague from Litomyšl, he would surely have been seeking the company of new friends in Prague.?

Kořenský left us a second recollection of gatherings at the Neff home in a lecture broadcast on radio on 19 August 1934 and also published in print. ${ }^{8}$ Although he devoted far more room to Dvořák in this slender volume than in the previous publication, he still did not give us any new facts about the composer, unfortunately. From the information in

5) Táborský mentions other figures: František Táborský, Ladislav Čelakovský, Josef Klvaňa, Josef Kuffner, Eduard Jelínek, Ferdinand Lachner, Pavel Durdík. See TÁBORSKÝ, František: Jan Neff, český obchodník a moravský buditel (Jan Neff, Czech Merchant and Moravian Revivalist), in: Jan Neff 1832-1932, Miloš and Vladimír Neff, Praha 1932, pp. 55-56. For more about those gatherings, see VAVROUŠEK, Bohumil: Josef Kořenský. Př́rodovědec, pedagog, cestovatel a spisovatel (Životopisný nástin k jeho 90. narozeninám) (Josef Kořenský. Naturalist, Pedagogue, Traveller, and Author - An autobiographical sketch for his $90^{\text {th }}$ birthday), in: Dr. Josef Kořenský. Životopisná stat' a hrst přátelských vzpomínek k jeho devadesátce (A biographical essay and a handful of friendly reminiscences for his ninetieth birthday), Ed. Grégr a syn (Grégr and Son Edition), Praha 1937, p. 16 (hereinafter VAVROUŠEK).

6) KOŘENSKÝ, Josef: Naše pražské večírky (Our Prague Dinner Parties), in: František Táborský. Hrst statí a prátelských vzpomínek k jeho sedmdesátce (A Handful of Essays and Friendly Reminiscences for His Seventieth Birthday), B. Vavroušek, Praha 1928, p. 81. There is a quotation of this reminiscence in O. Šourek: ŠOUREK, p. 93 (op. cit. in footnote no. 4).

7) TODOROVOVÁ, Jiřina - CHOVANEČEK, Jan: Kolem světa. Sbírka fotografíz cest Josefa Kořenského v Náprstkově muzeu asijských, afrických a amerických kultur (Around the World. A collection of photographs from the journeys of Josef Kořenský at the Náprstek Museum of Asian, African, and Native American Cultures), National Museum, Praha 2011, p. 14 (hereinafter TODOROVOVÁ - CHOVANEČEK).

8) KOŘENSKÝ, Josef: Hostem u dobrých přátel. Přednáška, kterou proslovil ředitel dr. Josef Kořenský v pražském rozhlase dne 19. srpna 1934 (A Guest with Good Friends. A lecture given by the director, Dr. Josef Kořenský on the radio in Prague on 19 August 1934), pp. 8-10. The book does not identify the publisher or printer, and it is also undated. Probably only a few specimens were printed privately. I have found only two specimens in Czech libraries (at the library of the Antonín Dvořák Museum under shelf mark CDO 015 and at the Municipal Library of Prague, where it is held as a rare book, shelf mark HC 1217.a). 
the text, one may infer that he drew on the text by Otakar Šourek from the book devoted to Jan Neff, ${ }^{9}$ to which he did not make any personal contribution, but which he cited at the end of his radio reminiscences. ${ }^{10}$ In the lecture, he mentioned the growing popularity of Antonín Dvořák, who was later invited to the Neff home as a respected artist, and from this one may infer that Kořenský remained a guest there at least until the mid-1880s: "With his Slavonic Dances and operas, Dvoŕák became more and more famous, and he no longer visited the Neff family as a tutor, but instead was enthusiastically welcomed to the dinner parties as a most esteemed guest. He was enchanted by the singers' lovely voices, so he agreed to provide the accompaniment with the greatest enthusiasm." Kořenský also makes an interesting reference to Tchaikovsky, which implies a clear connection between Jan Neff's Russian friends, Antonín Dvořák, and Pyotr Ilyich Tchaikovsky's visit to Prague in 1888: "Sometimes Prof. Masaryk would stop by [he began visiting the Neff home after he arrived in Prague in 1882 author's note] with the Russian priest Apraksin and his wife. The Orthodox cleric left behind something that was long remembered with gratitude, especially for those who were able to meet the celebrated composer Tchaikovsky in Apraksin's home and to see him together with Antonín Dvoŕák at the table among friends." Nikolai Petrovich Apraksin, an Orthodox priest in Prague, was a regular guest in the Neff home. On 13 February 1888 he visited Tchaikovsky in Prague and showed him around the city. Three days later (on 16 February), all three met for a dinner of the Russian circle, for which Mrs. Apraksin was the hostess. ${ }^{11}$

\section{Fellowship of the "Long Table"}

According to his contemporaries, another gathering of intellectuals that Kořenský frequented was called the "Long Table", and he encountered Dvořák there as well. Vavroušek is not on the list of people who belonged to this group, but it may be assumed that he got his information from witnesses:

"One of the most interesting evening forums from which Korenský was never absent was the large group of bachelors and married men, often with their better halves, known as the 'Long Table' and consisting of representatives of the sciences, arts, literature, and industry, along with the actress Charvátová; this diverse company met every day from the $1880 \mathrm{~s}$ until the Great War regularly from 7 p.m. until 9, at first at the restaurant $U$ Choderri, later at Kolár's Restaurant on Celetná Street, then at the Hotel Paris, and finally at the Municipal House near the Powder Tower. Some jokingly called it the Lord's Supper, and the ill informed with sharp tongues, seeing the long table with all of its places taken in the great hall on an elevated platform, whispered to each other: 'Those are the thieves who squandered so much money on the building here!' Among the regular visitors or apostles in attendance were J. Kořenský, the engineers F. Křrzz and R. Jahn, the architect Rozšlapil, Prof. L. Píč, F. Mareš, J. Hlava, the authors J. Vrchlický, A. Jirásek, B. Kaminský, and K. B. Mádl,

9) ŠOUREK, pp. 64-98 (op. cit. in footnote no. 4).

10) In the text, Šourek also refers to Kořenský’s first text; see footnote no. 6.

11) KUNA, Milan: Čajkovskij a Praha (Tchaikovsky and Prague), Supraphon, Praha 1980, pp. 20, 29-30. 
the artists V. Hynais and Myslbek, the musicians Dvoŕák and Ondřčcek, the director Hellich, the pomologist Thomayer, and Dr. Klumpar. Sometimes Ig. Herrmann, Jar. Kvapil, A. Klášterský and others came as well." ${ }^{2}$

From the collection of reminiscences about Kořenský, from which his biographical sketch is taken, we also find a reminiscence by Jaroslav Kvapil, ${ }^{13}$ the librettist of Rusalka, who was a member of this group, and he gives a list of people from ca. 1887 and onwards. To the list of names above he adds Slukov, Kolár, and Hlava. It is not entirely clear what the years were when Dvoŕák attended these gatherings, because there are no other sources. From these reminiscences, however, one can deduce that at the "Long Table", Dvořák may have met Jaroslav Kvapil, later the librettist for Rusalka, or one of the musicians from the Ondříček family.

"Perhaps none of us have seen so much of the world or been abroad so many times as Josef Korenský, and yet there are few people with whom it is so comfortable at home as with this former globetrotter, who for decades would alternate his Smichov schoolroom with the habitats of giraffes and kangaroos, yet hardly would he have returned from this or that faraway place, and he was again at home with his friends at the Long Table, formerly at the restaurant U Choderrio, then at Mayer's on Celetná Street, and finally at the Municipal House - alas at the Municipal House, where the only one left of the famed old guard of the 1890s, when he would come, was Korensky!! What a collection of people that was half a century ago and in the years that followed! Sitting at that long table, I see Vrchlický and Jirásek, Myslbek and Hynais, Hlava and Thomayer, Dvořák and Ondř́ček, Slukov and Kolár - and I should take care not to leave out František Křžžik, the other ninety-year-old among us these days, in fact a mere fourteen days older than today's celebrant."14

\section{Kořenský and the Dvořáks}

One of the impulses for Kořenskýs trip around the world was the World's Fair held in Chicago from 1 May to 30 October 1893. He did not set out on his journey alone; he was joined by the brewer and landholder Karel Řezníček, who also partially funded the journey. ${ }^{15}$

The purpose of his trip was not merely sightseeing, but also collecting. In Prague, Kořenský was probably closest to the family Vojta Náprstek, where he came calling almost daily. ${ }^{16}$ Another possible connection between Kořenský and Dvořák was Josef Václav Sládek, one of the best friends of Josefina Kounicovás husband Václav Kounic. ${ }^{17}$

12) VAVROUŠEK, p. 15 (op. cit. in footnote no. 5).

13) KVAPIL, Jaroslav: Posledni od dlouhého stolu (The Last of the Long Table), in: Dr. Josef Kořenský. Životopisná stat' a hrst prátelských vzpomínek k jeho devadesátce (Dr. Josef Kořenský. A biographical essay and a handful of friendly reminiscences for his ninetieth birthday), Ed. Grégr a syn, Praha 1937, p. 60 (hereinafter KVAPIL).

14) KVAPIL, p. 60 (op. cit. in footnote no. 13).

15) TODOROVOVÁ - CHOVANEČEK, p. 21 (op. cit. in footnote no. 7).

16) TODOROVOVÁ - CHOVANEČEK, p. 18 (op. cit. in footnote no. 7).

17) See the correspondence between J. V. Sládek and V. Kounic and between J. V. Sládek and J. Kořenský, literary estate of J. V. Sládek, kept at the LA PNP, unprocessed. 
Kořenský sent the Náprstek family regular reports about his journey, and they followed its progress with interest. He had also arranged with them that he would send a parcel with items that he would acquire while abroad, and he would also send up-to-date reports on his travels, and he did so conscientiously: "Very often, the pilgrim would remember the Náprsteks' home with picture postcards and longer letters, which were followed with great interest by all visitors to the reading room." ${ }^{18}$ Before his journey, he also asked the administrative committee of the Museum of the Kingdom of Bohemia for written permission to obtain new items for the museum's natural history collection. ${ }^{19}$ He received permission on 20 March 1893 from the president of the museum's administrative committee..$^{20}$

The Dvořáks, who were then living in New York with two of their children, Otilie and Antonín, were told about Kořenskýs trip by Terezie Koutecká, Anna Dvořák's sister, in a letter dated December 1892. Mrs. Koutecká and her mother were in Prague caring for the four Dvořák children who had remained at home (Anna, Magdalena, Otakar, Aloisie). When Kořenský gave a lecture in late 1892 about his planned journey (apparently for the purpose of finding a partner for the journey), he also mentioned his plan to visit Dvořák in New York:

"You may have heard something about the headmaster Kořenský, that on 1 February he's setting out on a journey around the world, which is supposed to last a year, so he's probably leaving on 1 February and will probably go to New York first. About a week ago he gave a lecture at the Municipal Forum about his journey, and among other things, he mentioned that he would be looking you up in New York and would invite himself for dumplings and cabbage. He's looking for someone to travel with him because travelling is cheaper and more pleasant for two." ${ }^{\prime \prime}$

The Dvoŕáks had been planning to return to Bohemia for holiday in 1893, but in the end they decided to stay and to spend their entire holiday with the whole family in Spillville, Iowa, Josef Kovařík’s birthplace. ${ }^{22}$ Dvořák's mother-in-law Klotilda Čermáková was originally to have accompanied the children, but when she refused to come to America because of her fear of the difficult voyage, Terezie Koutecká willingly accepted the task. ${ }^{23}$ At the end

18) KODYM, Stanislav: Dům u Halánkủ. Vzpomínky na Vojtu Náprstka (The House U Halánků. Remembering Vojta Náprstek), Československý spisovatel (The Czechoslovak Writer), Praha 1955, p. 139.

19) Kept at the Archives of the National Museum (hereinafter the ANM), Registry Office of the National Museum, carton 38, no. 91.

20) Kept at the ANM, Registry Office of the National Museum, carton 38, no. 109.

21) Letter to the family of T. Koutecká from A. Dvořák, 7 Dec. 1892, kept at the NM-MAD, inv. no. S 76/1243.

22) The Czech-American Josef Jan Kovaří (1870-1951), a native of the American town Spillville (Iowa), was a violinist and violist and later a member of the New York Philharmonic. Above all, he was a close friend and colleague of Antonín Dvořák.

23) It is no wonder that Klotilda Čermáková was afraid of the voyage. One should remember that in 1893 she was already 70 years old, and crossing the Atlantic involved considerable discomfort. Although the safety of ocean crossings was constantly improving every year, the danger of shipwrecks or of fire onboard continued. Epidemics represented another risk. The spread of disease was especially severe in the steerage ( $3^{\text {rd }}$ class), where most of the travellers were poor emigrants going to America. The conditions for the travellers in steerage were very bad. According to Polišenský: "the steerage was divided into sections with twenty bunks that were just 2 feet wide, i.e., $66 \mathrm{~cm}$, and they were stacked three on top of each other.” POLIŠENSKÝ, Josef: 
of February, it was settled that the children would be coming to New York from Prague together with her and with the Weinfurts, a married couple from Pilsen.

"We wanted to come to Bohemia this year, but we have decided that Mrs. Koutecká, my sister-in-law, will bring the other children to America in May. Then there is a family from Pilsen, the Weinfurts, who are also coming here and will take our children and help my sister-in-law on her journey, which is quite difficult with the children. And really, I would like to get to see America now that I have four months of holiday."

As Kořenský states in his travelogue, because of the World's Fair in Chicago, the ships of the company North German Lloyd that sailed from Bremen were constantly crowded. For this reason, it was necessary to secure a ticket several weeks in advance. ${ }^{25}$ While Kořenský got his tickets for the voyage on the SS Havel through the Bremen firm Alois Kareš ( $1^{\text {st }}$ class), Martin Weinfurt arranged the tickets for the Dvoŕák family ( $2^{\text {nd }}$ class $) .{ }^{26}$ The SS Havel was one of Lloyd's fastest and most modern ocean liners. It could carry 274 passengers in $1^{\text {st }}$ class, 148 in $2^{\text {nd }}$ class, and 384 in $3^{\text {rd }}$ class (in the "steerage"). ${ }^{27}$

Koutecká began organising the journey very actively with the assistance of Martin Weinfurt (1852-1896), who had lived in America until 1889; while there, he married Anna Kyselová, the daughter of Bohemian emigrants. ${ }^{28} \mathrm{He}$ was the treasurer of the Central School Association in Prague, where František Táborský and František Ladislav Rieger were also working. ${ }^{29}$ Mrs. Koutecká told M. Weinfurt that she would like to take the same ship as Josef

Úvod do studia dějin vystěhovalectví do Ameriky I. Obecné problémy dějin českého vystěhovalectví do Ameriky 1848-1914 (Introduction to the Study of Czech Immigration to America I. General issues of the history of Czech immigration to America 1848-1914), Karolinum, Praha 1992, p. 23. Regarding illness, it should not be overlooked that most of the passengers were suffering from seasickness.

24) Letter from A. Dvořák to Marie Bohdanecká, 20 Feb. 1893. In: Antonín Dvořák. Korespondence a dokumenty. Kritické vydání (Correspondence and Documents. Critical edition), ed. Milan Kuna et al., vol. 3, Supraphon, Praha 1989, pp. 180-181 (hereinafter ADKD). The letter is privately owned.

25) KOŘENSKÝ I, pp. 5-6 (op. cit. in footnote no. 3).

26) Letter from Terezie Koutecká to Anna Dvořáková, 7 Apr. 1893, kept at the NM-MAD, inv. no. S 76/1250.

27) Another outstanding feature of the ships sailing from Bremen and Hamburg was the nautical postal service established in 1891 with a special post office where parcels were sorted. The ships sailing from Bremen and Hamburg were generally the most reputable. The two cities had set up quarantined areas for emigrants where all of them were sanitised, and mandatory medical examinations were introduced in 1892 for emigrants on Germany's eastern borders. KOŘENSKÝ I, pp. 6, 24, 31 (op. cit. in footnote no. 3).

28) Martin Weinfurt's application for residency is kept at the Archives of the City of Pilsen (hereinafter AmP), residency records, AmP collection; birth records: State Regional Archives in Pilsen (hereinafter SOA), Collection of public records, birth records for 1844-1868, Štěnovice 07, f. 59; death records: SOA, Collection of public records, death records for 1892-1897, Pilsen 088, f. 369.

29) See Weinfurt's signature on Diplomas of True Membership of the Central School Association in Prague (signatures: chairman Dr. Fr. Lad. Rieger, director: Fr. Táborský, vice chairman: Frant. Kneidl, Dr. Jan Janda, treasurer: Mart. Weinfurt), n.d., kept at the AmP, acquisition no. LP 9785, shelf mark Mš 11 . In the sources, he is listed as a freeholder and as the owner of a house on Klatovská Street in Pilsen; see the application of Martin Weinfurt, owner of the villa and garden at the address 998/4 Klatovská Street in Pilsen for approval of dividing a parcel into two construction sites, kept at the AmP, Registry Office, inv. no. 16576, file shelf mark 157/III 1894, ref. no. 1017. According to Kořenský, he was the secretary of the Pilsen Chamber of Commerce. See the letter from Josef Kořenský to Josefa Náprstková, 22 May 1893, kept at the NM-NpM, Vojta Náprstek collection, no. 51/410. 
Kořenský. ${ }^{30}$ In a letter to the Dvořáks, she also mentions four other acquaintances travelling by the same ship, but she does not give their names: "The headmaster Mr. Kořenský and four more gentlemen known to me will be on the same ship with us. I am greatly looking forward to my reunion with you in America." ${ }^{31}$

The family took the express train to Bremen on Sunday, 21 May at 3 p.m. The journey from Bremen then began on Tuesday, 23 May at 8 a.m.; first, the travellers had to take a special morning train to Bremerhaven..$^{32}$ Kořenský met up with Terezie Koutecká, the children, and Mr. and Mrs. Weinfurt in Bremen, as he said in a letter to Josefa Náprstková, the wife of Vojta Náprstek:

"We like it in Bremen. At Karešs (Jelinek), all of our Czech compatriots caught up with us, and they are trying to do everything for us that they can see that we would want. [...] I'll send you a list of everybody sailing on the SS Havel. Mrs. Koutecká, Mr. Dvoŕák's sister-in-law, also stopped by today. Travelling with her and with his wife is Mr. Weinfurt, secretary of the Pilsen Chamber of Commerce. His wife is a native-born American (with Czech parents). He has lingered in New York for twenty years, and he has offered to serve willingly as my Cicero."33

\section{On board the SS Havel}

The decks for first and second class were separate for the sake of the comfort of the firstclass passengers, ${ }^{34}$ so Kořenský visited the Dvořáks in the area for $2^{\text {nd }}$-class passengers: "The steamship was full, and Mrs. Dvoř was glad she had got a place in $2^{\text {nd }}$ class. So I left the $1^{\text {st }}$-class area to visit her." ${ }^{35}$ According to Kořenský, there were 12 Czechs on board the ship, but he did not mention their names. ${ }^{36}$ There were no serious problems on the voyage except that most of the passengers were seasick the first and second nights. ${ }^{37}$ Things were the worst on the third night, but it was the third night for which we have an account from a letter by Kořenský's companion Karel Řezníček:

"The third night on board the ship was the worst as our colossal ship rocked violently as if being reduced to splinters - the women and children lying next to my cabin in the steerage, mostly emigrants from Poland, were becoming ill, and there was moaning, weeping, and prayer I couldn't sleep, and I began to feel ill - although it did not last long - I went out on deck for fresh air because down below everything had been shut tight, and near the heaters where I am sleeping, it's terribly stuffy. I recovered quickly, and now I'm completely well... [...] Today we have had thick fogsince 4 a.m., and the ship is giving a warningblaston its foghorn every five minutes and is sailing

30) Letter from Terezie Koutecká to Anna Dvořáková, 7 Apr. 1893, kept at the NM-MAD, inv. no. S 76/1250.

31) Letter from Terezie Koutecká to Anna Dvořáková, 28 Apr. 1893, kept at the NM-MAD, inv. no. S 76/1252.

32) KOŘENSKÝ I, p. 9 (op. cit. in footnote no. 3; numerous later quotes do not refer to footnote no. 3).

33) Letter from Josef Kořenský to Josefa Náprstková, 22 May 1893, Vojta Náprstek collection, no. 51/410.

34) KOŘENSKÝ I, p. 12.

35) Letter from Josef Kořenský to Otakar Šourek; see footnote no. 1. The person in question was Terezie Koutecká.

36) KOŘENSKÝ I, p. 17.

37) KOŘENSKÝ I, p. 26. 

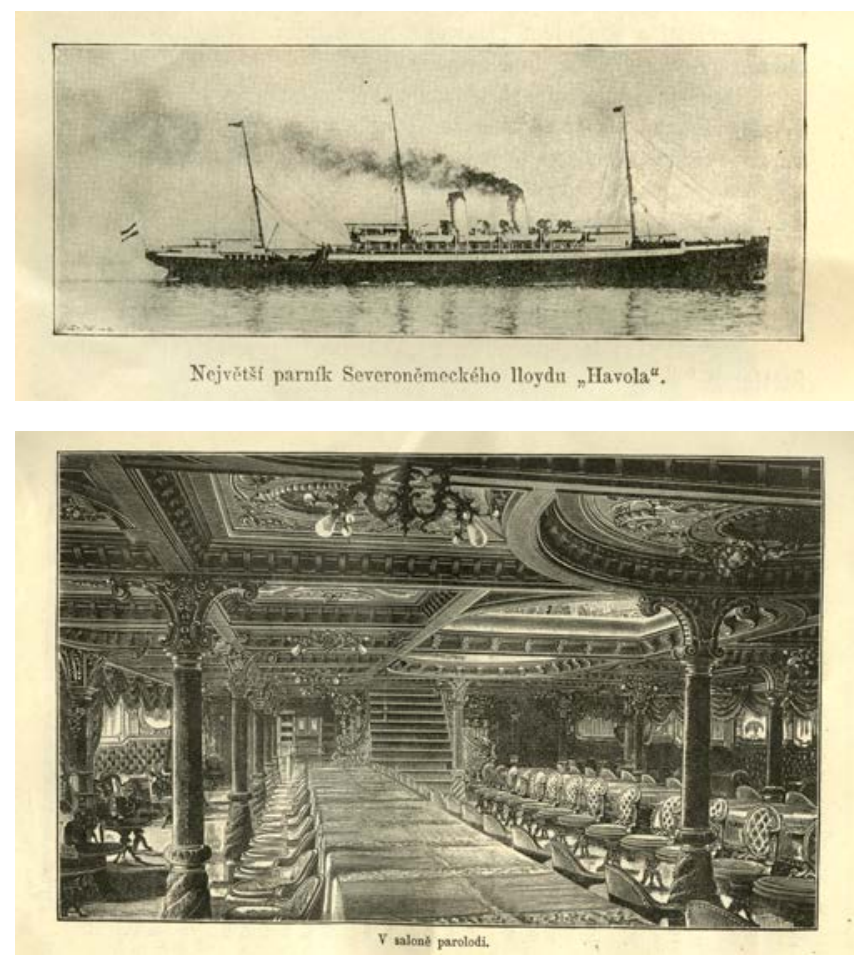

The SS Havel and engraving of the ship's salon / Lod' Havel a rytina lodního salónu

Picture in Kořenský's travelogue Journey around the World, Part I, p. 11, 13 / Vyobrazení v Kořenského cestopisu Cesta kolem světa, I. díl, s. 11, 13 more cautiously because of the poor long-distance visibility."38

Dvořák was greatly looking forward to seeing his children, as is shown by the composer's previous correspondence sent to friends in Bohemia. ${ }^{39}$ While his children were making the difficult journey, he finished his Symphony No. 9 in EMinor "From the New World", and at the end of the score he made a note about the delivery of a telegram informing him that they had landed in the English city Southampton: "Fine. Praise God. Completed on the $24^{\text {th }}$ day of May 1893 at 9 óclock a.m. Antonín Dvorák. The children have arrived in Southampton! (1:33 p.m. a telegram arrived.)"40 Josef

Kovařík drew Otakar Šourek's attention to this comment in a letter he sent him in 1927: “One day, upon returning home from the conservatoire, he informed his wife that he had decided to have the children brought from Prague. His wife agreed, so the next day, tickets were arranged for the ocean crossing by the children, who were to be accompanied on the long journey by Mrs. Koutecká, the sister of the maestro's wife. After this decision the maestro calmly went back to work, and at the very time when he finished the score of this magnificent work (around the $24^{\text {th }}$ of May, if I am not mistaken), a cablegram arrived from England, from Southampton, with the news that the children are on their way to America, and everyone is healthy!', as can be seen from a note written on the maestro's manuscript. In his excitement, the maestro forgot to write the trombone parts in some of

38) Letter from Karel Řezníček to an unknown addressee, 29 May 1893, kept at the NM-NpM, Karel Řezníček collection, no. 1/6.

39) Letter from Antonín Dvořák to Emil Kozánek, 12 Apr. 1893, ADKD 3, pp. 184-188: "The children and my sister-in-law Mrs. Koutecká are coming here; they are leaving Prague on 23 May and will take the SS Havel from Bremen, so if the Lord God wills it, on 31 May, I'll be seeing face to face the children I have been missing for so long!"’ The letter is privately owned.

40) The manuscript score is kept at the NM-MAD, inv. no. $S 76 / 1483$. 


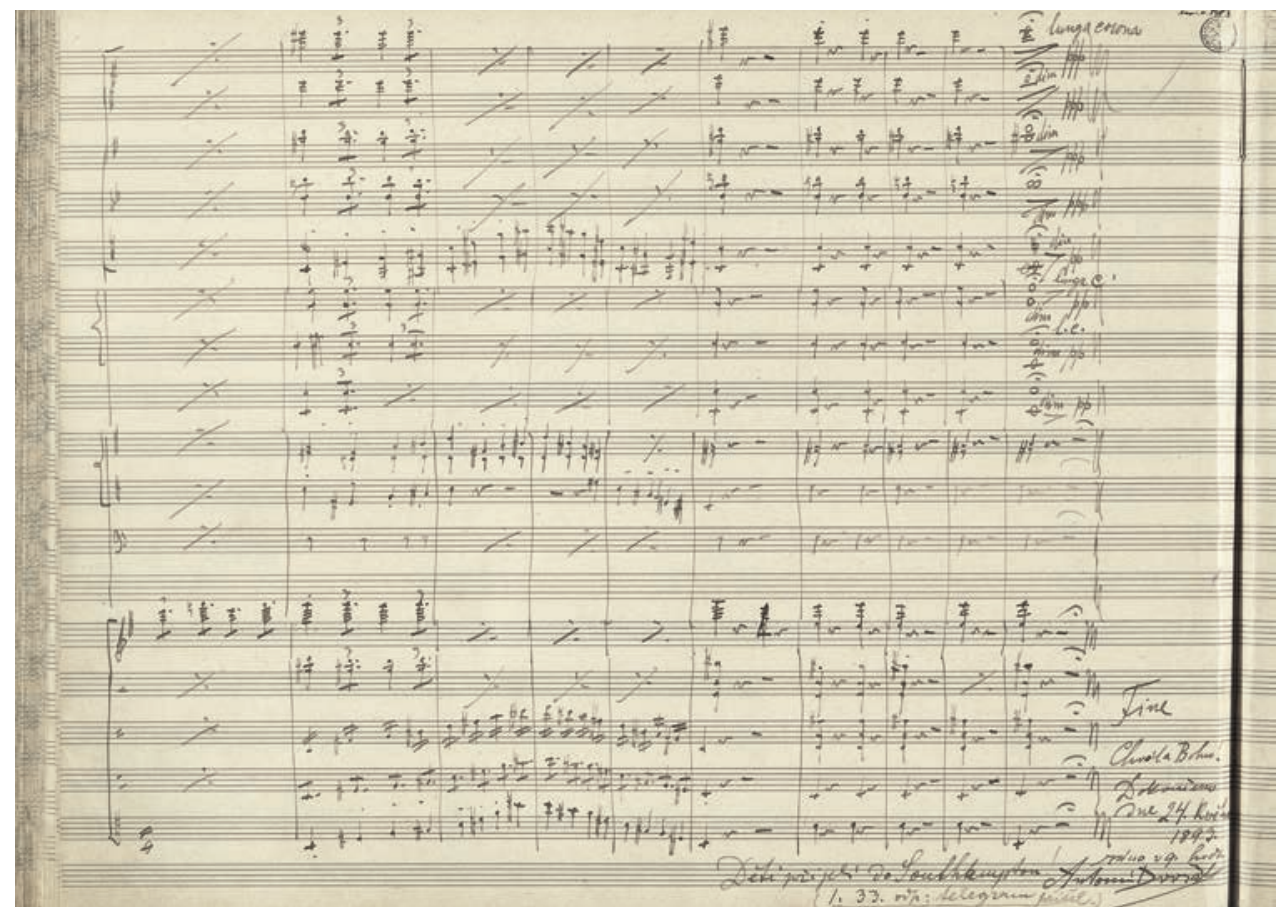

Last page of the manuscript of Dvořák's Symphony No. 9 in E minor "From the New World" with the composer's inscription about his children's arrival in Southampton / Poslední strana rukopisu Dvořákovy Symfonie č. 9 e moll „Z Nového světa" se skladatelovým přípisem o příjezdu dětí do Southamptonu NM-ČMH-MAD S 76/1482

the last bars of the symphony." Jarmil Burghauser refuted Kovařík's story on the basis of a detailed study of the manuscript. According to him, the third trombone and tympani parts may have been added after the receipt of the telegram in question, and not later in Spillville after Kovař́k pointed it out while copying the score, as Kovař́k claims in his memoirs. ${ }^{42}$ According to his comment, Dvoŕák finished the score at 9 a.m., so the afternoon telegram could not have been the cause of his carelessly leaving out the trombone and tympani parts. ${ }^{43}$

\section{Together at the boarding house}

The ship arrived in New York on 31 May 1893 at 4 p.m. In his diary, Kořenský made an entry about his first American encounter with Dvoŕák, which made a great impression on

41) NOVÁ, Kateřina - VEJVODOVÁ, Veronika: Nejraději mne tituloval indiánem. Americké vzpomínky na Antonína Dvořáka (English version of the book: Three Years with the Maestro. An American remembers Antonín Dvořák), Národní muzeum (National Museum), Praha 2016, pp. 47, 60; in the English version of the book pp. 46, 62 (hereinafter NOVÁ - VEJVODOVÁ).

42) See NOVÁ - VEJVODOVÁ, pp. 59-60 (op. cit. in footnote no. 41), in the English version of the book p. 62.

43) BURGHAUSER, Jarmil - KUNA, Milan: Antonín Dvořák. IX. symfonie e moll Z Nového světa op. 95. Komentár (Antonín Dvořák. Symphony No. 9 in E Minor, "From the New World", Op. 95. Commentary), in: Antonín Dvořák. IX. symfonie e moll Z Nového světa op. 95. Facsimile (Antonín Dvořák. Symphony No. 9 in E Minor, "From the New World”, Op. 95. Facsimile), Thomas Music Publishing Prague-Edice Muzeum (Museum Edition), Praha 2004, p. 12. 
him: "At four o'clock in Hoboken. Dvoŕák at the harbour with his family and children, who were carrying flowers for their younger siblings. Our maestro was weeping tears of joy when he saw his loved ones on deck, having been separated from them by the ocean for nearly a whole year." ${ }^{\prime 4}$ Dvoŕák was obviously moved. And no wonder, when his separation from his four children had lasted nearly nine months.

Kořenský and Dvořák only had the opportunity to be together from 31 May until 2 June, when the composer and his family departed for Spillville. After spending a night at the Hotel Belvedere, Kořenský moved to the boarding house where Dvořák and his family went for lunch. The house, which belonged to a Mrs. Wehrle, was very close to the composer's New York apartment and to the conservatoire where he was teaching:

"Then as far as Mrs. WEHRLE is concerned, here in America she kept what was called a 'BOARDING HOUSE', 427, where it was possible to rent a furnished apartment and to have meals, but even persons not living there could go there to eat. Something similar, I think, to a 'pension' in Europe. At first, the Dvoráks went there for lunch and supper, but later only for lunch." ${ }^{5}$

In Kořenskýs notes we find three entries for encounters with Dvořák - the first time on the second day after arrival in New York at lunch at the boarding house (1 June 1893), the second time for lunch and a visit together to the conservatoire, and the third time on the day before the family left for Spillville (2 June 1893). At the boarding house in New York, Kořenský found himself in the company of not only Dvořák, but also two other musicians who were passing through New York on their way to Chicago for the World's Fair - the violinist Karel Ondříček (1863-1943) ${ }^{46}$ and the cellist Artur Krása (1868-1929). ${ }^{47}$

The Dvořáks had already heard about Ondříček's trip to America from Josefina Kounicová in January 1893: "There was also a newspaper report in yesterday's Národní listy that Karel Ondriček had left his position at the National Theatre, because he is said to have received a wonderful offer to come to America." 48 Klotilda Čermáková also tried to establish contact with Ondříček before his departure, as Terezie Koutecká writes in a letter to Dvořák family: "Grandmother was looking for Mr. Ondřiček on the very day when your letter arrived. The woman he was living with told her that he had departed for America on that very day. The woman said he had been engaged with Mr. Krása by a certain agent from Berlin." ${ }^{* 9}$ According

44) Kořenskýs's diary; see footnote no. 2.

45) NOVÁ - VEJVODOVÁ, p. 149; in the English version of the book p. 159 (op. cit. in footnote no. 41).

46) ČERNUŠÁK, Gracian: Ondříček, Karel [entry], in: Československý hudební slovník osob a institucí, 2. sv., M-Ž (Czechoslovak Musical Encyclopaedia of People and Institutions, vol. 2, M-Ž), Státní hudební vydavatelství (State Music Publishing), Praha 1965, p. 224.

47) ŠTĚDROŇ, Bohumír: Krása, Artur [entry], in: Československý hudební slovník osob a institucí, 1. sv., A-L (Czechoslovak Musical Encyclopaedia of People and Institutions, vol. 2, A-L), Státní hudební vydavatelství (State Music Publishing), Praha 1963, p. 736.

48) Letter from Josefina Kounicová to the family of Antonín Dvořák, 21 Feb. 1893, ADKD 7, pp. 39-42. Kept at the NM-MAD, inv. no. $576 / 534$.

49) Letter from Terezie Koutecká to Anna Dvořáková, before 1 May 1893, kept at the NM-MAD, inv. no. S 76/1263. 
to the newspaper reports, Ondříček arrived in New York on 4 May. According to a report in the newspaper Pokrok západu: "On 4 May Mr. Karel Ondřiček arrived in New York. He is the younger brother of Mr. František Ondríček, the Czech violin virtuoso of worldwide fame. The younger Mr. Ondřiček, who is likewise a first-class violinist and has excellent future prospects, is on his way to Chicago, where he has an engagement. ${ }^{\prime 50}$ From other newspaper reports, we learn about a benefit concert that Ondříček and Krása gave on 21 May at New York's Central Opera House together with V. Raboch, their Czech compatriot, ${ }^{51}$ to raise money for the Bohemian National Hall in New York (built between 1895 and 1897).52

\section{Stereoscopic photographs and Alfred Baštýry, Johnny-on-the-spot in New York}

Of the other Czechs who graced the circle of Bohemian artists and intellectuals in New York at the time when Antonín Dvořák was living there and when Josef Kořenský made his brief visit, Alfred Baštýř should not be overlooked. According to the sources, Dvořák met regularly with "Dr. Baštýŕ in New York. ${ }^{53}$

The Baštýř and Dvořák families knew each other from Prague - Alfred's father Moses Baštýř (1835-1894) was a well-known Prague dentist. ${ }^{54}$ His son Alfred (1865-1942) studied the same field (graduating from the Faculty of Medicine in 1887). For a time, he abandoned his dentistry practice in Prague because of an offer to work with an American physician in New York. ${ }^{55}$

50) Češi v Americe (Czechs in America), in: Pokrok západu (Progress of the West, Omaha, Nebraska), 10 May 1893, vol. 22, no. 4, p. 12.

51) We know very little about this musician. Newspapers only refer to him as a virtuoso. See Dalibor, 27 Feb. 1897, vol. 19, nos. 15-16, p. 116. This might have been Václav Raboch, who played at the opening of New York's Carnegie Hall on 5 May 1891. See BINKOWSKI, Carol J.: Opening Carnegie Hall. The Creation and First Performances of America's Premier Concert Stage, McFarland and Company, Jefferson (North Carolina) 2016, p. 117. Kořenský mentions him in his notes as a pianist, a violinist, and apparently also a composer (see the transcription of the notes below).

52) The newspaper Týdenní hlasatel (Weekly Herald) reprinted a report from the newspaper New Yorské Listy. See [New Yorské Listy piśí], in: Týdenní hlasatel (Weekly Herald, Chicago, Ill.), vol. 1, 17 May 1893, no. 42, p. 1: "A special musical treat has been prepared for our Czech public. Mr. Karel Ondříček, the superb violinist and first concertmaster of the National Theatre in Prague, and Mr. Artuš Krása, the principal cellist at the National Theatre, are giving a big concert together on 21 May at the Central Opera House on 67th Street with the collaboration of the renowned virtuoso Prof. V. Raboch. Those three names are our guarantee that the words 'special musical treat' are not an empty phrase. Mr. K. Ondříček and Mr. A. Krása, who have come together to New York and will be staying here for some time before setting off on a further artistic pilgrimage around America, are artists in the truest sense of the word, and we do not doubt that the concert they are giving will attract lively interest among the Bohemian public, and especially when we observe that a third of the net earnings from the concert will go to the benefit of the Bohemian National Hall."

53) Josef Kovařík also mentions him in letters to Otakar Šourek. See NOVÁ - VEJVODOVÁ, p. 94, footnote no. 260; in the English version of the book p. 101, footnote no. 254 (op. cit. in footnote no. 41). Baštýr is erroneously identified here, however.

54) TRNKA, Miroslav: Není Baštýř jako Baštýr (One Baštýř is not like another), Rodopisná revue (Genealogy Revue) on-line, 2009, vol. 11, no. 2, p. 24. See http://rodopisna-revue-online.tode.cz/2-09_soubory/24trnka-bastyr.pdf

55) BAŠTÝR̆, Alfréd. Br. Alfred Baštýř (1. prosince 1901) (Brother Alfred Baštýř - 1 December 1901). In: HARTL, Antonín: Stavba. Sborník zednářských prací, sv. 2, Hledajicí v temnotách. Vzpomínky nejstarších bratří (The Edifice. 


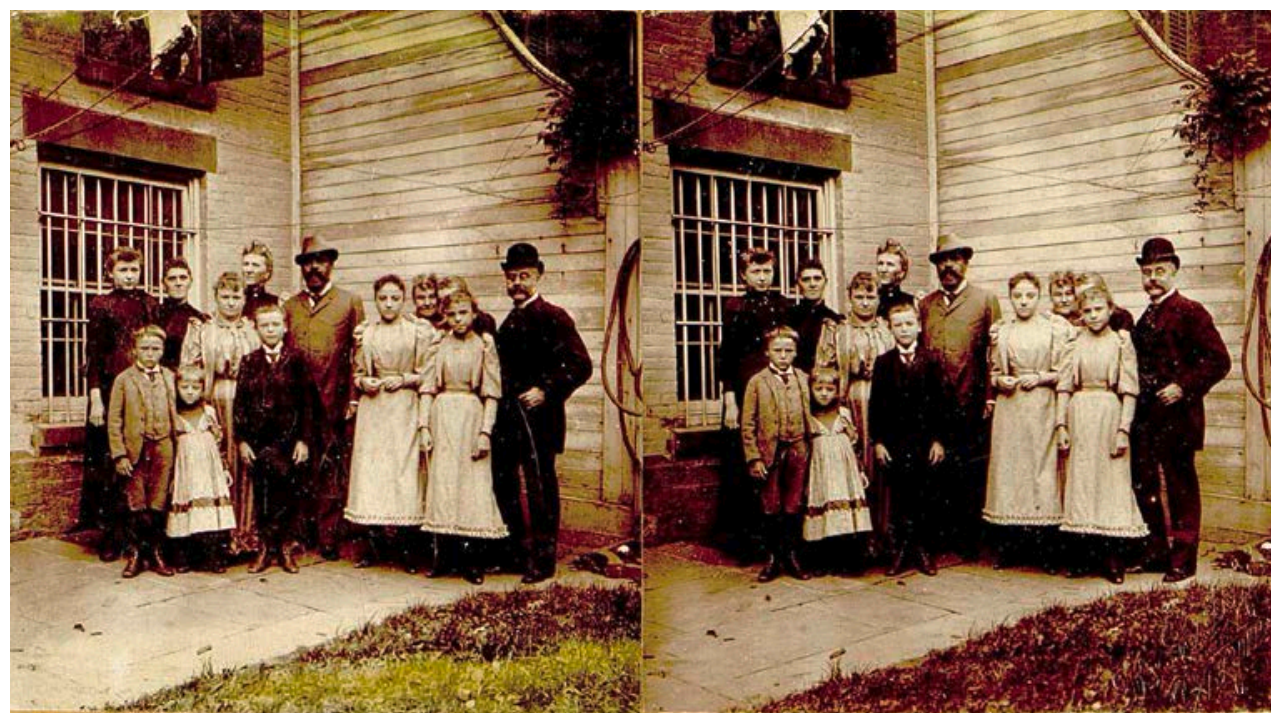

Antonín Dvořák with his family and friends in New York / Antonín Dvořák s rodinou a přáteli v New Yorku Original stereoscopic photograph / Originál stereoskopické fotografie, Alfred Baštýŕ, 1893 NM-ČMH-MAD S 226/1093

According to J. J. Kovař́k, he also came to America because of the World's Fair in Chicago. ${ }^{56}$ From Terezie Kouteckás letter, we know that he visited Dvořák a few times at his apartment in New York before her arrival: "I have spoken with old Dr. Baštýř, and he told me his son was already in America, that he had written from New York, that he had been at your place several times for dinner etc."

Baštýř was also a man of many interests: a collector, inventor, amateur radio operator, and later a film entrepreneur. ${ }^{58}$ He was also an avid stereoscopic photographer. ${ }^{59}$ In his notes and

An Anthology of Masonic Works, vol. 2, Searching in the Darkness. Recollections of the Eldest Brethren), J. Thon, Praha 1932, pp. 43-52 (hereinafter BAŠTÝŘ).

56) NOVÁ - VEJVODOVÁ, p. 94; in the English version of the book p. 101 (op. cit. in footnote no. 41).

57) Letter from Terezie Koutecká to Anna Dvořáková, 14 May 1893, kept at the NM-MAD, inv. no. S 76/1252.

58) Baštýr reveals more about himself in the cited set of Freemasonry memoirs; see BAŠTÝR̆, p. 43 (op. cit. in footnote no. 55).

59) MÁDROVÁ, Kamila: Alfred Baštýřr(1865-1942). Lékař ve službách nových médií (The Physician in the Services of New Media), in: České, slovenské a československé dějiny 20. století (Czech, Slovak, and Czechoslovak History of the $20^{\text {th }}$ Century), ed. Sylva Sklenářová, vol. 6, Oftis - Gaudeamus, Ústí nad Orlicí - Hradec Králové, 2011, pp. 207-215. According to the preserved catalogue cards at the National Technical Museum, we can infer that Baštýř had intended to create a private archive of his stereoscopic photographs; see MÁDROVÁ, Kamila: Baštýr Alfred (1.5.1865 - 21. 8.1942)(1911-1938). Inventár. NAD č. 733, evidenční pomůcka č. 283, Národní technické muzeum - Archiv pro dějiny techniky a průmyslu (National Technical Museum - Archives for the History of Technology and Industry), Praha 2008; MÁDROVÁ, Kamila: Alfred Baštýřr (1. 5. 1865 - 21. 8. 1942), stomatolog, filmař, radioamatér, svobodný zednár (Alfred Baštýr, 1 May 1865-21 Aug. 1942, Dentist, Filmmaker, Amateur Radio Operator, Freemason), in: Dějiny věd a techniky (History of Science and Technology), vol. 42, 2009, no. 3, pp. 205-206. Some of Baštýř's stereoscopic photographs have been preserved at the Department of Theatre of the National Museum (the oldest Czech theatrical photography from a performance of Imre Madách's play The Tragedy of Man at the National Museum in 1892, National Museum - Historical Museum, inv. no. 32F420, 32F421). 
travelogue, Kořenský mentions in several places that Baštýř took photographs in New York. He photographed the arrival of the ship with Kořenský and Dvořák's children: "After turning over the baggage, I was again as free as a bird, and we left the harbour accompanied by Dr. Baštýr, who was staying in New York at the time, and like a real Johnny-on-the-spot, he had captured the arrival of the 'SS Havel' in his photographic cassette." ${ }^{\prime 0}$ Unfortunately, these photographs have not been preserved if they were ever even developed. Baštýr also photographed Kořenský with friends on an excursion to Coney Island. ${ }^{61}$

Fortunately, Baštýr has left us two stereoscopic photographs of the Dvořák family made in the courtyard of the house where they were living in New York. These have been preserved apparently only because one developed copy (I assume that there were at least two) remained in New York with Josef Kovařík, who sent it to Otakar Šourek in Prague in 1929 together with identification of the persons depicted:62 "II have also found three group photographs. I have labelled them I - II - III and written on each one the names of all of the people. These pictures were taken by Dr. Baštýr from Prague, who was visiting America at the time of the World's Fair in Chicago. I regret that I have no other group photographs, but I am glad that at least these have been preserved. The maestro strongly disliked being photographed, but he did not protest at all against these pictures, which were taken by Dr. Baštýr. Being glad that he again had his whole family back together, the maestro would probably have been happy to be photographed all day long." 3

Baštýřs first photograph was apparently taken before the arrival of the children with Terezie Koutecká, because it depicts only Mr. and Mrs. Dvořák with their daughter Otilie and their son Antonín, Josef Kovařík, and the sister of the Dvořáks' landlady (Mrs. Siebert; the landlady's name was Mrs. Drew) with her daughter (Sadie Siebert). ${ }^{64}$ According to Kovařík, the second photograph was taken after the children arrived, sometime between 31 May and 3 June, when the whole Dvořák family departed for Spillville. ${ }^{65}$ These stereoscopic photographs depict all of the family members. ${ }^{66}$ The third photograph mentioned by Kovaŕík may have been taken on the steps of the house in New York, again with all of the members of the Dvoŕák family, but that photograph is not stereoscopic, and on the basis of the reproduction made from an unknown original, ${ }^{67}$ neither the dating nor the author of the photograph can be determined. Terezie Kouteckás correspondence implies that she, too, apparently tried to get these photographs from Baštýř but she probably did not succeed. ${ }^{68}$

60) KOŘENSKÝ I, p. 42.

61) "Dr. Baštýr took a stereoscopic photograph with the appropriate staffage." J. Kořenský’s diary, 3 June 1893, no page numbers. See footnote no. 2.

62) NOVÁ-VEJVODOVÁ, p. 94; in the English version of the book p. 101 (op. cit. in footnote no. 41).

63) Ibid, p. 94.

64) Kept at the NM-MAD, inv. no. $5226 / 1093$.

65) Dvořák's Czech-American calendar with notes, kept at the NM-MAD, inv. no. S 226/884.

66) In addition, it depicts Sadie Siebert, Mrs. Siebert, Mrs. Drew, and a neighbour, Dr. Lindemann. Kept at the NM-MAD, inv. no. S 226/1092.

67) Both copies are kept at the NM-MAD, inv. nos. S 226/1091 and $1801 \mathrm{Il}$.

68) Koutecká had already written to the Dvořáks about Baštýr on 10 December 1894, and she told them that he was setting up a practice in Prague with everything in "the American manner". See the letter from T. Koutecká to the family of A. Dvořák, 11 Dec. 1893, kept at the NM-MAD, inv. no. S 76/1256. The letter 


\section{Transcription of excerpts from Josef Kořenský’s diary}

Josef Kořenskýs diary kept at the Náprstek Museum of Asian, African, and American Cultures in the Kořenský estate is part of a set of the traveller's travel logs and diaries from the years 1883-1913. This diary from 1893 is the first of a set of six diaries from his trip around the world (nos. 1, 2 - America, no. 3 - America, Hawaii, Japan, no. 4 - China, Malaysia, Java, no. 5 - Malaysia, Ceylon, India, no. 6 - India, Egypt).

The diary in a half leather binding measuring $98 \times 151 \mathrm{~mm}$ contains a total of 93 lined sheets, and the pages are not numbered. There is writing in the diary from the first page to the last, with only three pages left blank in the first part, and one at the end. It contains handwritten comments mostly in pencil, but also in pen in red ink in places (mainly at the beginning and end where addresses of his contacts in America are written). The comments in pencil are supplemented in places by inscriptions in red and blue pencil. Kořenský also used a red pencil for underlining, apparently when working on his travelogue. The coloured inscriptions also date from that time. Kořenský had apparently already highlighted words by underlining them in regular pencil when actually writing them. The diary was plentifully used on his journeys, so Kořenskýs comments are very poorly legible. For orientation in the diary, one can use the dates that are written as headings of individual chapters.

Portions of the diary were selected for transcription based on their relevance and their connection to Antonín Dvořák and to musical and social life in New York. Passages that describe, for example, the school system in New York or the construction of skyscrapers were omitted. Kořenský devotes more attention to Dvořák in his diary than in the travelogue, but the transcription refers to the travelogue where the latter presents certain information in a more expanded form. Dating in the transcription is supplemented based on Kořenskýs diary. The diplomatic transcription of the Czech original makes no changes to the text. Although the pages are not numbered, page numbers have been added by counting from the first page of the diary that bears writing.

[31 May 1893]

[p. 41]

The mail will have long since arrived in N. Y. before the SS Havel gets to Hoboken. ${ }^{69}$ Then the physician and the customs officers board the SS Havel. We are waiting between the citadels.

also tells us that Baštýř was the Dvořáks' dentist: "I think I would like to go to Dr. Baštýr for those promised photographs, but I can't. He lent me a few American songs to copy. When Mrs. Štěpánková from Pardubice was here, she sang the songs through and liked them. She wouldn't give me peace until I lent them to her, saying she would translate them and send them right back - as of yesterday, it has been 14 days, and she hasn't sent me anything, and without them, I can't go to Baštýr either for photographs or for the tooth that has been hurting me for a long while." Letter from Terezie Koutecká to Otilie Dvořáková, 29 Apr. 1894, kept at the NM-MAD, inv. no. S 76/1265.

69) Before the ship sailed into the harbour, a postal steamer came to the ship: "Many people come along on the postal steamboat to see their friends on the SS Havel, and the postal official distributes the newspapers, letters, and telegrams addressed to the 'SS Havel' to the passengers." KOŘENSKÝ I, p. 40. 
The physician arrived, accepted the reports and a case of wine, and the examination was over for $2^{\text {nd }}$ class and $1^{\text {st }}$ class. ${ }^{70}$ The examination was stricter in $3^{\text {rd }}$ class, where each person had to walk past the doctor. ${ }^{71}$

The customs officials also arrived. They sat down at a table, and each of us announced our names, where we were going, of what country we were citizens, how many bags we had, and what was in them. The inspection lasted a total of over 2 hours. ${ }^{72}$

Everything was found to be in order. We sail on at 4:30. We're glad we're arriving before 6 oclock. A ship of immigrants is anchored in front of us. Among the 2,000 people, they found about 14 who were sick. They'll all be waiting a few days in quarantine.

[p. 42$]$

At four o'clock in Hoboken. Dvoŕák at the harbour with his family and children, bringing flowers to the youngest. Our maestro wept tears of joy when he spotted his beloved family on deck, having been separated from them by the sea for nearly a whole year. Dr. Baštýr also welcomed the new arrivals with his photographic cassette, and he recognised us before we saw him. A staircase was drawn up to the ship and leaned against the side. It was difficult to get down to customs with all the noise and bustle that accompanied us as if some potentate were approaching New York. Flowers were being tossed onto the deck by long-expected acquaintances with the waving of scarves on both sides, and the noise and uproar drowned out all conversation. Some people were weeping for joy, while others were laughing and rejoicing that the ship had made it to shore safely. A line of colossal ships was anchored there. ${ }^{73}$ Also [?]. We went down into customs: A huge hall.

[p. 43$]$

Telegrams (Cablegrams). ${ }^{74}$

70) The case of wine was a gift from the captain. KOŘENSKÝ I, p. 40.

71) "After the post, the medical doctor comes, who accepts a case of Rhine nectar as a kind gift from the captain, and he also accepts the report from the ship's physician about the state of the passengers' health in first and second class, and with the words 'all right - everything is in order', the passengers from the steerage start passing by the doctor for a stricter check-up." KOŘENSKÝ I, p. 40.

72) "Finally, the customs officials also arrive on the 'SS Havel'. They sit down at a table and on special forms they record our names, citizenship, destination, number of bags, and their contents. We affirm the truth of our statements by our signatures instead of by swearing an oath.” KOŘENSKÝ I, pp. 40-41.

73) Kořenský does not mention meeting Dvořák at the harbour in his travelogue. KOŘENSKÝ I, p. 41: "After many preparations, the anchor of the SS Havel rattled again. The ship was showered with fragrant bouquets and blossoms, and as we crossed the bridge in the noisy commotion and touched the ground of the New World for the first time, there were endless embraces. Friends fell into embrace with each other, laughing and weeping for joy, and misted vision sanctified intimate bonds on all sides."

74) KOŘENSKÝ I, p. 42: "Then an agent of the telegraphic cable company came to us and presented a form and a price list, according to which the price for every word sent to Prague was 34 cents, and a few minutes later, our friends in old Europe would already be reading our brief cablegram: 'Greetings!'” Kořenský had already mentioned cablegrams in his book: "There are about a dozen underwater cables laid in the depths of the Atlantic Ocean, and as an undying memorial, they remind the world of the glorious name Morse, that great benefactor of mankind, who has joined worlds together with electromagnetic power and has turned dead wires into living nerves." KOŘENSKÝ I, p. 26. Kořenský also mentions the cablegram frequently in his reminiscences of Antonín Dvořák. See NOVÁ - VEJVODOVÁ, p. 60, in the English version of the book pp. 6162 (op. cit. in footnote no. 41). 
Things there are organised by initials, K. R. V., according to the person's name. They bring all of the baggage up there from the ship, marked with the appropriate letter. We take the ticket that we got from the customs officer while on board the ship after making the customs declaration, and we turn it over at a special desk, whereupon a customs officer goes with us to the bags, and in a moment the inspection is over. Dr. Baštýr performed a wonderful service for us there. He befriended us, and like a Johnny-on-the-spot New Yorker, he led us to the ferryboat, ${ }^{75}$ and soon, exhausted, we were cruising (the baggage was turned over to an express service to be taken to the Hotel Belvedere, 50 cents per item) ${ }^{76}$ from Hoboken to the city, then by electric elevated train to our hotel - where acquaintances from the SS Havel again gathered. First night at the Belvedere ${ }^{77}$ - Krása, Ondř́ček, and the painter Procházka stopped by in the evening to take us to the Pilsen Beer Pub.

[p. 44]

\section{June, Thursday}

Our guide was the faithful Dr. Baštýr, then Mr. Weinfurt. A tour of apartment buildings. The housekeeper of fourteen-storey Welsh buildings complete furnished (Salons, parlours, smoking rooms etc.) wearing livery

Structures: steel frames. Carrying bricks and mortar on their shoulders using special carriers.

[p. 46]

Moving to a boarding house

Harry Wehrle

17 E 125

Irving place

N. Y.

See below, everything for 11 dollars per week

At this boarding house, maestro Dvorák has lunch with his family. Lunch together. A narrow, noisy area was called the dining room. Dvorák was there with his wife, sister-inlaw, 6 children, a servant, Kovařik, us three, (Dr. Vogel), Dr. Baštýr. It was arranged that the three of us would also live and have meals there. The rooms are very comfortable, and the food with Czech dumplings tasted very good. For breakfast there were usually pancakes like

75) The ferryboat carried passengers from the harbour to the city.

76) Kořenský has more to say about the baggage: "I immediately turn the bags over to a commissioner who will handle their transport to the hotel. Overseas, one does not find public porters like in Prague. There, each man is not working on his own behalf, but instead belongs to a company, an enterprise of men working together that is much more efficient and arranges transport of baggage and parcels all over the world. There, a porter does not grab heavy chests and bags in order to heave them onto his back in the sweat of his brow and drag them around the great city like a beast of burden; instead, he loads them onto a specially built cart and has the things drawn by horses from one hotel to another, and from house to house. [...] The fee for delivery depends on the number of items and the distance. Ordinarily one pays about 50 cents per item." KOŘENSKÝ I, p. 42.

77) Detailed description of the hotel: ibid, pp. 51-55. 
on the ship. We're far from the excessive noise. Wide beds - made for two at a time. There are no rooms with two beds. ${ }^{78}$

[p. 47]

Visit to the conservatoire of music. A private house with smallish rooms. The caretaker is a negro.

126-128 E 17 str. N. Y.

President Mrs. Jeanette M. Thurber.

Dvoŕák is attempting to introduce negro motifs to America's national music (minor keys). The professors are paid by the hour. Many people from important positions are on the board.

Picture of Dvorák in the hall. Theatre for rehearsing the season. School of Drama.

Kovarík a pupil of the teacher. He comes from Spillville in Winneshiek County (near Milwaukee), Iowa. ${ }^{79}$

[p. 48]

[2 June 1893]

Lunch with Dvoŕák. Parting. He leaves tomorrow for Spillville, a Czech settlement.

[p. 65]

[5 June 1893] $]^{80}$

Went to Seidl's concert in the evening. On the programme: Liszt, Mascagni, Grieg, Wagner,

Dvorak (Bohemian Dances). ${ }^{81}$

[p. 73]

[8 June 1893]

Weekly price at Wehrle's with beer and everything 11 dollars.

Visited Raboch. The saying that every Czech is a musician has again shown itself to be true.

Preludes, fugues, concertos for piano and solo violin.

78) "I moved from the expensive Belvedere House the very next day to a cheaper pension (boarding house) with a weekly price of about 10 dollars ( 25 gulden), and at our maestro Dvořák's hospitable table, we drank to our health in the New World." Ibid, p. 55.

79) In his travelogue, Kořenský summarises his visit to the conservatoire as follows: "At the time, the conservatory's school years was again over, and its director, maestro Dvořák, was getting ready to spend his summer holiday in Spilville, a Czech community in the state of Iowa, about as far from New York as Prague is from the edge of Siberia. So the muses at the American conservatoire fell silent for a few months, and all I got to see was the empty hall of the modest building to which the Dvorák's fame had brought the Bohemian maestro to serve as director.” Ibid, p. 55.

80) The last day when Dvořák could have met with Kořenský was 4 June, because on 5 June the Dvořák family departed for Spillville, so Dvořák could not have been present at this concert. Kořenský left New York definitively on 15 June 1893. See TODOROVOVÁ - CHOVANEČEK, p. 24 (op. cit. in footnote no. 7).

81) Kořenský attended one of the popular concerts that Anton Seidl conducted. See A Series of Seidl Concerts. The Sun, 4 June 1893, vol. 60, no. 277, p. 10: "Madison Square Garden To-Morrow, Monday evening, June 5, at 8:15, summer opening of the Annual Promenade Concerts by ANTON SEIDL and his great Metropolitan Orchestra. Soloists: Mr. Viktor Herbert, Mr. A. Seifferth”. Dvořák’s Slavonic Dances, either the first set (Op. 46, B83) or the second (Op. 72, B147), were apparently on the programme. 


\section{Conclusion}

Kořenský had the opportunity of meeting Dvořák in New York in the course of three days, from 31 May until 2 June 1893. Although they knew each other from Prague's intellectual circles, their conversations were not very extensive. According to Kořenský, the composer did not talk much. Forty years later, he summarised his encounter with Dvořák in a letter to Otakar Šourek:

\section{"Dear Sir!}

In by book Trip around the World (vol. I, p. 55), I make mention of Dvoŕák on one page. The book is found at the Bohemian Museum, the Náprstek Reading Room (Bethlehem Square), and the University Library. In May 1893 I sailed from Bremen on the same ship that was taking Dvoŕák's relatives to New York. They were going to join Dvoŕák, who had already left for America earlier. The steamship was full, and Mrs. Dvor. was glad she got a place in $2^{\text {nd }}$ class. For this reason, I visited her from $1^{\text {st }}$ class. When we landed on the shores of America, Dvoŕák was waiting for the steamboat. We saw him from the deck, and we showered him with flowers. In New York we lived together in a pension. Dvoŕák did little talking, in line with his reputation, but he did take me to his conservatoire. It was a modest institution, founded by an admirer of his.

If you happen to be in Smíchov, please come calling at the address Arbesovo námèstí no. 70. I live on the second storey of the District House. I am usually at home from 10 until 11 and from 3 until 4.

Until we meet again.

Yours faithfully,

Josef Kořenský

Prague-Smichov, 23 October '34"82

In New York, Dvořák was able to inform Kořenský about his stay there and about his work at the conservatoire as the director. ${ }^{83}$ Although the traveller has left us only a meagre account of his encounters with Dvořák, his notes and his travelogue document in detail not only the trip itself and New York in 1893, but also the contacts between Czech musicians and intellectuals who were overseas at the time. Thanks to the information from Kořenský, our impression of Dvořák's stay in New York has become more three-dimensional and authentic.

Address: Veronika Vejvodová, Muzeum Antonína Dvořáka, Ke Karlovu 20, 12000 Praha 2, Czech Republic E-mail:veronika_vejvodova@nm.cz

82) Letter from J. Kořenský to O. Šourek; see footnote no. 1.

83) This is implied by the information that Kořenský stated in his travelogue. There is an interesting comment about Dvořák's pay at the conservatoire: "How much America is able to remunerate persons who are supposed to lend prestige and fame to an enterprise shines forth from the fact that Dvorák's annual salary as director of the conservatoire was twice as much as the administrator of the entire Kingdom of Bohemia is paid for his services”. See KOŘENSKÝ I, p. 56. 


\section{Antonín Dvořák v zápiscích cestovatele Josefa Kořenského a česká společnost v Americe v roce 1893

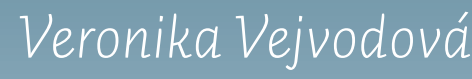

O stycích učitele a cestovatele Josefa Kořenského (1847-1938) s Antonínem Dvořákem (1841-1904) se z dosavadní odborné literatury dozvíme jen velmi málo. ${ }^{1}$ Ačkoliv Kořenský nepatřil do okruhu nejbližších Dvořákových přátel, je známo, že se oba muži znali z pražských vlasteneckých kruhů a že intenzivnější kontakt navázali v New Yorku na konci května a v první polovině června roku 1893. Okolnosti těchto setkání a další detaily z cesty do New Yorku, kterou Kořenský absolvoval na lodi spolu se sestrou Dvořákovy manželky Terezií Kouteckou a s Dvořákovými čtyřmi ze šesti dětí, zaznamenal Kořenský ve svém deníku, ${ }^{2}$ který později sloužil jako podklad pro sepsání jeho dvojdílného cestopisu Cesta kolem světa. ${ }^{3}$ Ani Kořenského deník, ani vydaný cestopis se dosud nestaly předmětem bádání dvořákovských odborníků.

\section{Hosté u Neffů}

Josef Kořenský, rodák ze Sušna na Mladoboleslavsku, byl učitelem a cestovatelem, který zážitky ze svých cest publikoval v cestopisech. Byl přítelem Emila Holuba, se kterým se seznámil v salónu manželů Náprstkových v domě U Halánků, kde se scházela vybraná intelektuální společnost a kam patrně sporadicky zavítal i Antonín Dvořák. S nimi udržoval velmi blízké vztahy a Náprstkovi také finančně podporovali jeho cesty. V letech 1874-1938 působil

Předložená práce vznikla za finanční podpory Ministerstva kultury v rámci institucionálního financování dlouhodobého koncepčního rozvoje výzkumné organizace Národní muzeum (DKRVO 2019-2023/23.I.a, 00023272).

1) Vztahem Kořenského a Dvořáka se chtěl zabývat Otakar Šourek. Svědčí o tom Kořenského dopis Šourkovi z 23. 10. 1934, uložen v Národním muzeu - Muzeu Antonína Dvořáka (dále NM-MAD), pozůstalost Otakara Šourka, č. př. 88/98.

2) Deník je uložen v Národním muzeu - Náprstkově muzeu asijských, afrických a amerických kultur (dále NMNpM), Sbírkové oddělení-Archiv, sign. Kořenský 3/33.

3) KOŘENSKÝ, Josef: Cesta kolem světa 1893-94. Díl I. Atlantický oceán, Amerika, Tichý oceán, Ostrovy Havajské, Žaponsko, J. Otto, Praha [mezi 1896 a 1902] (dále KOŘENSKÝ I); KOŘENSKÝ, Josef: Cesta kolem světa 1893-94. Díl II. Čína, Malajské souostroví, Cejlon, Indie, Rudé moře, Egypt, J. Otto, Praha [mezi 1896 a 1902]. 
jako učitel a později ředitel dívčí školy na Smíchově. Cesty podnikal především během školních prázdnin. Nejvíce se proslavil cestou kolem světa, kterou podnikl spolu se statkářem Karlem Řezníčkem v roce 1893.

Josef Kořenský se s Dvořákem poprvé setkal patrně v domácnosti rodiny obchodníka a vlastence Jana Neffa. Skladatel byl dle Otakara Šourka od roku 1873 domácím učitelem Neffových dětí a byl také pravidelně přítomen na společenských večerech, ${ }^{4}$ kam byli postupně zváni pražští a moravští vlastenci, ale i zástupci jiných slovanských národů (zejména Rusové a Poláci) z okruhu Neffových přátel a př́ibuzných. ${ }^{5}$ Zde se Dvořák jistě setkával s Kořenským, který byl zdejším pravidelným hostem, jak je doloženo ve dvou jeho vzpomínkách.

Svou první vzpomínkou Kořenský také jako jediný doložil, že Moravské dvojzpěvy kromě manželů Neffových a jejich vychovatelky Marie Blažkové zpívala také manželka Ladislava Čelakovského, Louisa Čelakovská.

„Druhým sňatkem vstupoval Jan Neffv nový život, a péči vzorné jeho choti a nadšené vlastenky stávala se pohostinná rodina častým shromáždištěm oddaných přátel. Moravské dvojzpěvy vítězného Dvořáka, provázené samotným mistrem na piano, propiojčovaly dýchánkưm slavnostního nádechu a radostné nálady u všech četných posluchačủ. Hlasy obou pěvkyň, jakými bývaly obyčejně pí. Marie Neffová a její př́telkyně pí. Čelakovská, chot’ vèhlasného botanika, uchvacovaly, a jen proto se ujimal velebný skladatel průvodu."

Dle tohoto údaje mohl Kořenský salón Neffových navštěvovat přibližně ve stejné době jako Dvořák, jelikož mladý Kořenský nastoupil jako odborný učitel na začátku školního roku 1874/1875 na dívčí měštanskou školu na Smíchově v Přívozní ulici a jako nově příchozí z Litomyšle do Prahy jistě vyhledával společnost nových pražských přátel.?

Druhou vzpomínku na setkání u Neffů zanechal Kořenský v přednášce přenášené rozhlasem 19. 8. 1934, která byla také vydána tiskem. ${ }^{8}$ Ačkoliv věnoval v tomto útlém sešitku

4) ŠOUREK, Otakar: Jan Neff a Antonín Dvořák, in: Jan Neff 1832-1932, Miloš a Vladimír Neffové, Praha 1932, s. 71-81 (dále ŠOUREK); Týž: Dvořák a Neffovi, in: Z Dvořákovy cesty za slávou. Hrst proslovů a článků, Hudební matice Umělecké besedy, Praha 1949, s. 41-67, 165-166; Týž: Život a dílo Antonína Dvořáka, část první, 1841-1877, 3. vydání, Státní nakladatelství krásné literatury, hudby a umění, Praha 1954, s. 225-227.

5) Táborský uvádí další osobnosti: František Táborský, Ladislav Čelakovský, Josef Klvaňa, Josef Kuffner, Eduard Jelínek, Ferdinand Lachner, Pavel Durdík. Viz TÁBORSKÝ, František: Jan Neff, český obchodník a moravský buditel, in: Jan Neff 1832-1932, Miloš a Vladimír Neffové, Praha 1932, s. 55-56. Dále o těchto setkáních: VAVROUŠEK, Bohumil: Josef Kořenský. Př́rodovědec, pedagog, cestovatel a spisovatel (Životopisný nástin kjeho 90. narozeninám), in: Dr. Josef Kořenský. Životopisná stat a hrst přátelských vzpomínek k jeho devadesátce, Ed. Grégr a syn, Praha 1937, s. 16 (dále VAVROUŠEK).

6) KOŘENSKÝ, Josef: Naše pražské večírky, in: František Táborský. Hrst statí a přátelských vzpomínek k jeho sedmdesátce, B. Vavroušek, Praha 1928, s. 81. Tuto vzpomínku citoval O. Šourek: ŠOUREK, s. 93 (op. cit. v pozn. 4).

7)TODOROVOVÁ, Jiřina - CHOVANEČEK, Jan: Kolem světa. Sbírka fotografíz cest Josefa Kořenského v Náprstkově muzeu asijských, afrických a amerických kultur, Národní muzeum, Praha 2011, s. 14 (dále TODOROVOVÁ - CHOVANEČEK).

8) KOŘENSKÝ, Josef: Hostem u dobrých přátel. Přednáška, kterou proslovil ředitel dr. Josef Kořenský v pražském rozhlase dne 19. srpna 1934, s. 8-10. Tisk je bez udání vydavatele a tiskaře, chybí také vročení. Jednalo se asi pouze o soukromý tisk v nákladu několika kusů. $V$ českých knihovnách jsem nalezla pouze dva výtisky 
Dvořákovi daleko větší prostor než v předchozí publikaci, bohužel o skladateli neuvedl žádnou novou skutečnost. Podle informací v textu lze usuzovat, že čerpal z textu Otakara Šourka z knihy věnované Janu Neffovi, ${ }^{9}$ do které sice osobně nepřispěl, ale na konci své rozhlasové vzpomínky ji citoval. ${ }^{10} \mathrm{~V}$ přednášce zmínil rostoucí popularitu Antonína Dvořáka, který byl později k Neffưm zván již jako vážený umělec, z čehož lze usuzovat, že Kořenský zůstal hostem této společnosti minimálně do poloviny osmdesátých let: „Svými Slovanskými tanci a operními skladbami stával se Dvořák pořád známějším a nedocházel k Neffovưm již jako domácí učitel, ale byl nadšeně vitán o večírcích jako nejváženějši host. Lahodné hlasy pěvkyň ho uchvacovaly, a proto se ujimal prưvodu vždy s největši ochotou." Zajímavá je také Kořenského zmínka o Čajkovském, ze které vyplývá patrná souvislost mezi ruskými přáteli Jana Neffa, Antonínem Dvořákem a návštěvou Petra Iljiče Čajkovského v Praze v roce 1888: „Občas se dostavovali prof. Masaryk [ten začal k Neffưm docházet až po příchodu do Prahy v roce 1882 - pozn. autorky] a ruský pop Apraxiň s chotí. Pravoslavný ten kazatel zanechal po sobě vděčnou památku, zvláště u těch, kteři mohli poznati v jeho domácnosti oslavovaného skladatele Čajkovského a viděti ho pohromadè u prátelského stolu s Antonínem Dvorákem." Nikolaj Petrovič Apraksin, pražský pravoslavný kněz, byl pravidelným hostem u Neffü. Dne 13. února 1888 navštívil v Praze Čajkovského a provedl ho po Praze. O tři dny později (16. února) se všichni tři zúčastnění setkali na večírku Ruského kroužku, jehož hostitelkou byla paní Apraksinová. ${ }^{11}$

\section{Společnost „Dlouhý stůl“}

Další intelektuální společnost, kterou Kořenský podle pamětníků navštěvoval a kde se setkával i s Dvořákem, byla společnost přezdívaná „Dlouhý stůl“. Vavroušek sám ve výčtu osobností této společnosti uveden není, dá se ale předpokládat, že informace čerpal od pamětníků:

„Jednou z nejzajímavějšich večerních besed, kde Kořenský nikdy nechyběl, byla početná společnost mládencư a ženatců, často i s jejich polovicemi, nazvaná ,dlouhý stůl' a skládajicí se z representantů vědy, umění, literatury a průmyslu, kterou doplňovala dramatická umělkyně Charvátová; tato pestrá společnost scházela se od 80. let až do světové války každý den pravidelně od 7. do 9. hod. zprvu u Chodèrů, později v Kolárově restauraci v Celetné, potom v hotelu ,Pařiž a posléze v Obecním domě u Prašné brány. Vtipkáři jí nazývali ,večeři Páně a neinformované zlomyslné jazyky, vidouce ve velkém sále na povýšené estrádě plně obsazený dlouhý stůl, šeptávali si: ,To jsou ti zloději, co tu prostavěli tolik peněz!' Z pravidelných návštěvníkư či apoštoli̊ chodili sem J. Kořenský, ing. F. Kř́ž, ing. R. Jahn, arch. Rozšlapil, prof. L. Píč, F. Mareš, J. Hlava, literáti J. Vrchlický, A. Jirásek,

(knihovna Muzea Antonína Dvořáka \{sign. CDO 015\} a Městská knihovna v Praze \{uloženo jako vzácný tisk, sign. HC 1217.a\}).

9) ŠOUREK, s. 64-98 (op. cit. v pozn. 4).

10) Šourek se také v textu odkazuje na první Kořenského text, viz pozn. č. 6.

11) KUNA, Milan: Čajkovskij a Praha, Supraphon, Praha 1980, s. 20, 29-30. 
B. Kaminský, K. B. Mádl, výtvarníci V. Hynais, Myslbek, hudebníci Dvořák, Ondříček, řed. Hellich, pomolog Thomayer, dr. Klumpar, občas přicházeli také Ig. Herrmann, Jar. Kvapil, A. Klášterský a j. ${ }^{\text {‘12 }}$

Ve sborníku vzpomínek na Kořenského, z něhož pochází jeho životopisný nástin, nalezneme také vzpomínku Jaroslava Kvapila, ${ }^{13}$ libretisty Rusalky, který byl členem této společnosti a uvádí výčet osobností cca kolem roku 1887 a dále. K výše zmíněným přidává Slukova, Kolára a Hlavu. Není zcela jasné, ve kterých letech tuto společnost Dvořák navštěvoval, jelikož chybí jakékoliv další zdroje. Z uvedených vzpomínek lze však vyvodit, že se u „Dlouhého stolu“ Dvořák mohl setkávat s Jaroslavem Kvapilem, pozdějším libretistou Rusalky nebo jedním z hudebníků rodiny Ondříčků.

„Snad nikdo z nás neviděl tolik světa a nebyl tolikrát v širokém světě jako Josef Kořenský, a préece s málokým je tak po domácku útulno jako s tímto někdejším globetrotterem, jenž po desetileti dovedl střidat svou smichovskou učebnu s krajinami žiraf a klokanů, a jenž sotvaže se z té, které Trantárie navrátil, měl zas nejbliž k svým práteli̊m u dlouhého stolu, kdysi u Chodèrü, pak u Mayera v Celetné ulici a nakonec v Obecním domě - ach v tom Obecním domě, kde už z někdejši slavné gardy let devadesátých zbyl, pokud tam ještě chodí, jediný Kořenský! Jaká to byla pred půlstoletím a v léta pozdějši společnost! Vidím u toho dlouhého stolu zasedat Vrchlického i Jiráska, Myslbeka i Hynaise, Hlavu i Thomayera, Dvořáka i Ondř́ćka, Slukova i Kolára - a pozor, abych nezapomněl, i Františka Křižika, toho druhého devadesátníka našich dní, dokonce o nějakých čtrnáct dní staršího, než je náš dnešní jubilant. "${ }^{\text {"4 }}$

\section{Kořenský a Dvořákovi}

Impulzem pro cestu kolem světa byla Kořenskému světová výstava v Chicagu, která se konala od 1. května do 30. října 1893. Na cestu se nevydal sám, společníkem mu byl sládek a statkář Karel Řezníček, který také cestu částečně financoval. ${ }^{15}$

Účel jeho cesty nebyl pouze poznávací, ale také sběratelský. V Praze měl Kořenský asi nejblíže rodině Vojty Náprstka, kam chodil téměř denně. ${ }^{16}$ Další spojnicí mezi Kořenským a Dvořákem mohla být osobnost Josefa Václava Sládka, jednoho z nejlepších přátel manžela Josefiny Kounicové, Václava Kounice. ${ }^{17}$

Kořenský o své cestě pravidelně informoval manžele Náprstkovy, kteří se zájmem sledovali její průběh. Zároveň byl s nimi domluven, že k nim bude zasílat balíky s předměty, které v cizině obstará, a také bude zasílat aktuální zprávy z cest, jak svědomitě činil: „Velmi

12) VAVROUŠEK, s. 15 (op. cit. v pozn. 5).

13) KVAPIL, Jaroslav: Poslední od dlouhého stolu, in: Dr. Josef Kořenský. Životopisná stat' a hrst prátelských vzpomínek k jeho devadesátce, Ed. Grégr a syn, Praha 1937, s. 60 (dále KVAPIL).

14) KVAPIL, s. 60 (op. cit. v pozn. 13).

15) TODOROVOVÁ - CHOVANEČEK, s. 21 (op. cit. v pozn. 7).

16) TODOROVOVÁ - CHOVANEČEK, s. 18 (op. cit. v pozn. 7).

17) Viz korespondence mezi J. V. Sládkem a V. Kounicem a mezi J. V. Sládkem a J. Kořenským, literární pozůstalost J. V. Sládka, uloženo v LA PNP, nezpracováno. 
často vzpomínal poutník na Náprstkův dìm pohlednicemi $i$ delšimi dopisy, které byly s velkým zájmem sledovány všemi návštěvníky čítárny." ${ }^{18}$ Před cestou také žádal správní výbor Musea Království českého o písemné povolení k získávání nových předmětů do přírodovědecké sbírky pro muzeum. ${ }^{19}$ Povolení mu bylo uděleno 20. března 1893 od prezidenta správního výboru muzea. ${ }^{20}$

O Kořenského cestě se Dvořákovi, v tu dobu usídleni spolu se dvěma dětmi Otilkou a Antonínem v New Yorku, dozvěděli od Terezie Koutecké, sestry Anny

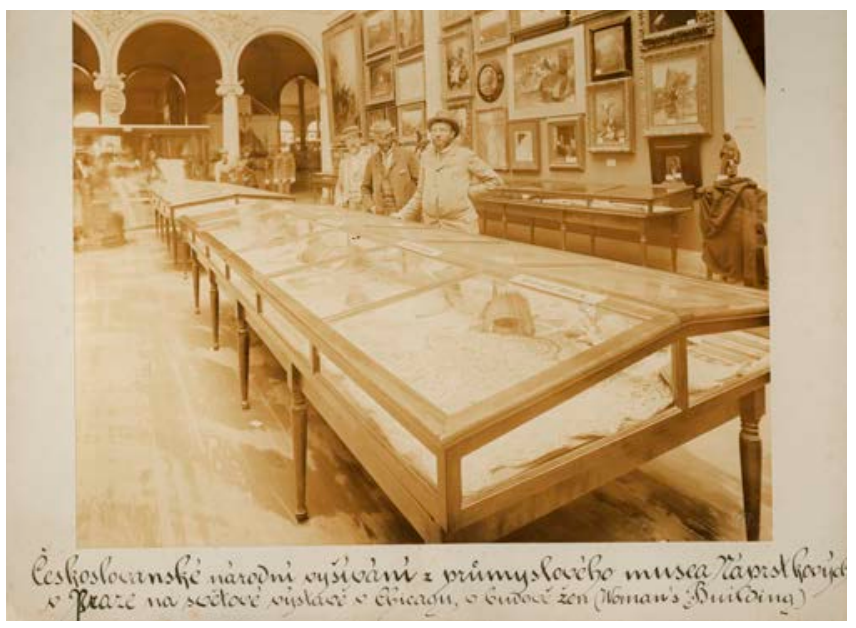

Josef Kořenský and Karel Řezníček at the World’s Fair in Chicago / Josef Kořenský a Karel Řezníček na světové výstavě v Chicagu Photograph by an unknown photographer, August 1893 / Fotografie, autor neznámý, srpen 1893

NM-NpM, collection of historical photographs, shelf mark 15.50. The photograph was also printed in the journal Světozor, 25 Aug. 1893, vol. 27, no. 41 (1366). /

NM-NpM, sbírka historických fotografií, sign. 15.50. Fotografie byla také otištěna v časopise Světozor, 25. 8. 1893, roč. 27, č. 41 (1366).

Dvořákové, z dopisu z prosince roku 1892. Koutecká se v Praze starala spolu se svou matkou o Dvořákovy čtyři děti, které zůstaly doma (Anna, Magdalena, Otakar, Aloisie). Když na konci roku 1892 Kořenský o své plánované cestě přednášel (patrně za účelem hledání společníka na cesty), zmínil se také o svém záměru Dvořáka v New Yorku navštívit:

„A což o řediteli Kořenským jste slyšeli, že 1. února nastoupí cestu kolem svèta, která má trvat rok, vyjede tedy 1. února asi a jede zaprve do Nového Yorku asi před týdnem držel $v$ měštanské besedè přednášku o své cestě zminil se mezi jinými, že Vás v Novém Yorku vyhledá a pozve se na knedliky se zelím. Hledá spolucestovatele, že ve dvou se cestuje levnèji a príjemněji. ${ }^{\text {‘21 }}$

Dvořákovi sice plánovali vrátit se na prázdniny 1893 do Čech, ale nakonec se rozhodli zůstat a prázdniny strávit s celou rodinou ve Spillville v Iowě, rodišti Josefa Kovař́ika ${ }^{22}$. Původním doprovodem pro děti měla být Dvořákova tchýně, Klotilda Čermáková. Když však odmítla do Ameriky odjet, protože se bála náročné cesty na lodi, její úlohy se ochotně

18) KODYM, Stanislav: Dům u Halánků. Vzpomínky na Vojtu Náprstka, Československý spisovatel, Praha 1955, s. 139.

19) Uloženo v Archivu Národního muzea (dále ANM), Registratura Národního muzea, karton 38, č. 91.

20) Uloženo v ANM, Registratura Národního muzea, karton 38, č. 109.

21) Dopis T. Koutecké rodině A. Dvořáka, 7. 12. 1892, uloženo v NM-MAD, inv. č. S 76/1243.

22) Čechoameričan Josef Jan Kovařík (1870-1951), rodák z amerického Spillville (Iowa), byl houslista, violista, později člen Newyorské filharmonie a především blízký prítel a spolupracovník Antonína Dvořáka. 
zhostila Terezie Koutecká. ${ }^{23}$ Ke konci února již padlo pevné rozhodnutí, že do New Yorku pojedou děti z Prahy spolu s ní a manželi Weinfurtovými z Plzně.

„Chtěli jsme prijet letos do Čech, ale ustanovili jsme se, že ostatní dítky v květnu přiveze do Ameriky švagrová paní Koutecká, pakjedna rodina z Plznè, Weinfurtovic, pojedou též sem a vezmou naše ditky a budou tak švagrové nápomocní na cestě, která je s dètmi dost obtižná. Pak bych prec také rád poznal Ameriku, když mám 4 mèsíce prázdniny. ${ }^{\text {.24 }}$

Jak uvádí Kořenský ve svém cestopisu, kvůli konání světové výstavy v Chicagu byly lodě společnosti Severoněmecký Lloyd, které vyplouvaly z Brém, stále přeplněny. Proto bylo potřeba zajistit si palubní lístek již několik týdnů dopředu. ${ }^{25}$ Zatímco Kořenský si lístky na cestu lodí Havel zajistil skrze brémskou firmu Alois Kareš (1. třídu), Dvořákovým zajištoval lístky Martin Weinfurt (2. třídu). ${ }^{26}$ Lod' Havel byla jedna z nejrychlejších a nejmodernějších, kterou společnost Lloyd disponovala. Pojala 274 cestujících 1 . třídy, 1482 . třídy a 384 3. třídy (tzv. mezipalubí). ${ }^{27}$

Koutecká začala velmi aktivně organizovat cestu za pomoci Martina Weinfurta (1852-1896), který žil do roku 1889 v Americe, kde se oženil s dcerou českých emigrantů Annou Kyselovou. ${ }^{28}$ Byl pokladníkem Ústřední matice školské v Praze, ve které působil také František Táborský nebo František Ladislav Rieger. ${ }^{29}$ Koutecká sama upozornila M. Weinfurta, že by si přála jet stejnou

23) Není divu, že Klotilda Čermáková měla z cesty lodí strach. Když pomineme fakt, že v roce 1893 jí bylo již 70 let, cestu přes moře provázela spousta nepř́ijemností. Ačkoliv se bezpečnost lodní dopravy každým rokem neustále zvyšovala, nebezpečí ohně na lodi či ztroskotání neustále trvalo. Dalším nebezpečím byly epidemie. Nemoci se šírily zejména z mezipalubí (3. třída), kde cestovali především chudí přistěhovalci do Ameriky. Cestovní podmínky v mezipalubí byly velmi špatné. Polišenský uvádí, že „mezipalubí bylo rozděleno do oddělení po dvaceti lůžkách, která měla šírku pouhých 2 stop, čili $66 \mathrm{~cm}$, a byla ve třech patrech nad sebou." POLIŠENSKÝ, Josef: Úvod do studia dějin vystěhovalectví do Ameriky I. Obecné problémy dějin českého vystěhovalectví do Ameriky 1848-1914, Karolinum, Praha 1992, s. 23. Co se týče nemocí, nelze nezmínit, že většina cestujících trpěla při plavbě nevolností.

24) Dopis A. Dvořáka Marii Bohdanecké, 20. 2. 1893. In: Antonín Dvořák. Korespondence a dokumenty. Kritické vydání, ed. Milan Kuna a kol., sv. 3, Supraphon, Praha 1989, s. 180-181 (dále ADKD). Dopis je v soukromém majetku.

25) KOŘENSKÝ I, s. 5-6 (op. cit. v pozn. 3).

26) Dopis Terezie Koutecké Anně Dvořákové, 7. 4. 1893, uloženo v NM-MAD, inv. č. S 76/1250.

27) Lodě vyplouvající z Brém a Hamburku vynikaly také tím, že na nich byla roku 1891 zřízena námořní pošta se zvláštním poštovním úřadem, kde se třídily zásilky. Lodě vyplouvající z Brém a Hamburku měly obecně nejlepší pověst. Obě tato města zřídila karanténu pro vystěhovalce, kde byli všichni dezinfikováni, a v roce 1892 byly zavedeny povinné lékařské prohlídky pro vystěhovalce na východních německých hranicích. KOŘENSKÝ I, s. 6, 24, 31 (op. cit. v pozn. 3).

28) Přihláška k pobytu Martina Weinfurta uložena v Archivu města Plzně (dále AmP), pobytová evidence, fond AmP; záznam o narození: Státní oblastní archiv v Plzni (dále SOA), Sbírka matrik, matrika narozených 1844-1868, Štěnovice 07, f. 59; záznam o úmrtí: SOA, Sbírka matrik, matrika zemřelých 1892-1897, Plzeň 088, f. 369.

29) Viz Weinfurtův podpis na Diplomech skutečného členství Ústřední matice školské v Praze (podpisy: předseda dr. Fr. Lad. Rieger, jednatel: Fr. Táborský, místopředseda: Frant. Kneidl, dr. Jan Janda, pokladník: Mart. Weinfurt), nedat., uloženo v AmP, poř. č. LP 9785, sign. Mš 11 . V pramenech je uveden jako soukromník a majitel domu v Klatovské ulici v Plzni, viz žádost Martina Weinfurta, majitele vily a zahrady čp. 998/4 na Klatovské tř. v Plzni, o schválení parcelace na dvě stavební místa, uloženo v AmP, Registratura, inv. č. 16576, 
lodí jako Josef Kořenský. ${ }^{30} \mathrm{~V}$ dopise Dvořákovým se také zmiňuje o dalších čtyřech známých, kteří cestují stejnou lodí, jejich jména však neuvádí: „Pan ředitel Kořenskýa ještě 4 známí pánové jedou tou samou lodí co my, velice se těši na shledání s Vámi v Americe. ${ }^{31}$

Rodina se vypravila vlakem v neděli 21. května ve tři hodiny odpoledním rychlíkem do Brém. Cesta z Brém pak započala v úterý 23. května v 8 hodin ráno; nejprve se cestující museli dopravit zvláštním ranním vlakem do Bremerhavenu. ${ }^{32}$ Kořenský se s Terezií Kouteckou, dětmi a manželi Weinfurtovými setkal již v Brémách, o čemž informoval v dopise Josefu Náprstkovou, manželku Vojty Náprstka:

„V Brémách se nám líbí. U Kareše (Jelínka) chytli se našich šosů všichni čeští krajánci a vynasnažuji se učiniti nám vše, co nám vidí na očích. [...] Pošlu Vám listinu všech, kteři plují po lodi Havole. Dnes dostavila se též pí. Koutecká, švagrová p. Dvořáka. Jede s ní a se svou manželkou p. Weinfurt, tajemník obchodní komory Plzeňské, jenž maje (za ženu) rozenou Američanku (z čes. rodiču), prodlel v N. Y. dvacet let a nabizí se mi za ochotného cicerona. ${ }^{\text {(33 }}$

\section{Na palubě lodi Havel}

Paluby první a druhé třídy nebyly společné kvůli pohodlí pasažérů 1 . třídy, ${ }^{34}$ proto Kořenský navštěvoval Dvořákovy v prostoru pro cestující 2. třídy: „Parník byl obsazen a pí. Dvoř. byla ráda, že dostala místo ve 2. třídè. Proto jsem ji z 1. třidy navštěvoval. ${ }^{\circledR 5} \mathrm{Na}$ lodi se podle Kořenského sešlo dvanáct Čechů, jejich jména však neuvádí. ${ }^{36}$ Plavba proběhla bez větších problémů, jen většina cestujících trpěla první a druhou noc mořskou nemocí. ${ }^{37}$ Nejhorší však byla třetí noc, o čemž svědčí dopis Kořenského společníka Karla Řezníčka:

„Třetí noc na lodi byla nejhorši za silného kolíbání našeho kolosa jak tes. třisky - vedle mé kabiny ležící ženy a dèti mezipalubníků, ponejvíce vystěhovalců, Poláků, se roznemohli, to bylo naříkání, pláče a modlení - nemohl jsem spáti $i$ mně se udèlalo špatně - netrvalo to však dlouho - vylezl jsem na palubu na čerstvý vzduch, neb dole bylo vše uzavřeno a pobliž přihřivačù, kde spím, strašně dusno, brzo jsem se opèt zastavil nyní jsem uplně zdráv... [...] Dnes máme od 4 hod. ráno silnou mlhu každých 5 minut dává lod'výstražný signál mlhovou piśt́alou a jede opatrnèji, je málo na dálku vidèt. ${ }^{38}$

spisová sign. 157/III 1894, ev. č. 1017. Podle Kořenského byl tajemníkem Obchodní komory Plzeňské. Viz Dopis Josefa Kořenského Josefě Náprstkové, 22. 5. 1893, uloženo v NM-NpM, fond Vojta Náprstek, č. 51/410. 30) Dopis Terezie Koutecké Anně Dvořákové, 7. 4. 1893, uloženo v NM-MAD, inv. č. S 76/1250.

31) Dopis Terezie Koutecké Anně Dvořákové, 28. 4. 1893, uloženo v NM-MAD, inv. č. S 76/1252.

32) KOŘENSKÝ I, s. 9 (op. cit. v pozn. 3, další četné citace již k pozn. 3 neodkazuji).

33) Dopis Josefa Kořenského Josefě Náprstkové, 22. 5. 1893, fond Vojta Náprstek, č. 51/410.

34) KOŘENSKÝ I, s. 12.

35) Dopis Josefa Kořenského Otakaru Šourkovi, viz pozn. č. 1. Jednalo se o Terezii Kouteckou.

36) KOŘENSKÝ I, s. 17.

37) KOŘENSKÝ I, s. 26.

38) Dopis Karla Řezníčka neznámému adresátovi, 29. 5. 1893, uloženo v NM-NpM, fond Karel Řezníček č. 1/6. 
Na své děti se Dvořák velmi těšil, o čemž svědčí předešlá skladatelova korespondence prrátelům do Čech. ${ }^{39}$ Během náročné cesty lodí, kterou děti právě prodělávaly, dokončoval Symfonii č. 9 e moll „Z Nového světa“ a na závěr partitury si poznamenal doručení telegramu informujícího o jejich přistání v anglickém Southamptonu: „Fine. Chvála Bohu. Dokončeno dne 24. května 1893 ráno v 9. hodin. Antonín Dvořák. Děti prijeli do Southamton! (1.33 odp: telegram přišel. “40 Na tuto poznámku upozornil Josef Kovařík Otakara Šourka v jednom z dopisů, které mu zasílal v roce 1927: „Jednoho dne při návratu z konservatoře oznámil své choti, že se rozhodl povolati ditky z Prahy. Pani souhlasila, a tak následujicího dne zaopatreny preplavní listky pro ditka, jichž měla na té daleké pouti doprovoditi paní Koutecká, sestra mistrovy choti. Po tomto rozhodnutí pracoval mistr klidně dále a právě když končil partituru tohoto velkolepého díla (nemýlím-li se, kolem 24. kvètna), přišel kabelogram z Anglie, ze SOUTHAMPTON, oznamujicí, že ,ditky jsou na cestě do Ameriky a vše zdrávo!', jak tomu svědči poznámka v mistrově manuskriptu. V tom rozčílení mistr v několika poslednich taktech sinfonie opomněl, pazauny! "“1 Kovaříkovu příhodu na základě detailního studia rukopisu vyvrátil Jarmil Burghauser. Podle něj mohl být part třetího pozounu a tympánů dopsán až po přijetí zmíněného telegramu, nikoliv později ve Spillville po Kovaříkově upozornění během opisování partitury, jak uvádí Kovařík ve svých vzpomínkách. ${ }^{42}$ Dvořák dle své poznámky dokončil partituru v 9 hodin ráno, odpolední telegram tedy nemohl být příčinou jeho nepozornosti a vynechání pozounů a tympánů. ${ }^{43}$

\section{Společně v boarding housu}

Lod' do New Yorku připlula 31. května 1893 ve čtyři hodiny odpoledne. Kořenský si do svého deníku zapsal první americké setkání s Dvořákem, které na něj udělalo velký dojem: „O čtvrté hodině v Hoboken. Dvořák v př́stavu s rodinou a dètmi, jež kytičky nesly svým mladším. Slzy radosti kanuly našemu mistrovi, když zahlédl na palubě své nejmilejší, od nichž dělilo ho moře téměr již celý rok. " ${ }^{44}$ Dvořákovo pohnutí bylo zřejmé. Není divu, když odloučení od jeho čtyř dětí trvalo téměř devět měsíců.

Kořenský se s Dvořákem měli možnost setkávat pouze od 31. května do 2. června, kdy skladatel s rodinou odjel do Spillville. Kořenský se po noci strávené v hotelu Belvedere přestěhoval do tzv. boarding housu, kam chodil Dvořák s rodinou na obědy. Tento dům majitelky paní Wehrle se nacházel velmi blízko skladatelova newyorského bytu a konzervatoře, kde vyučoval:

39)Dopis Antonína Dvořáka Emilu Kozánkovi, 12. 4. 1893, ADKD3, s. 184-188: „Děti i paní švagrová píKoutecká príijedou sem, a sice vyjedou z Prahy 23. května po lodi ,Havel'z Brém, a tak dá pánbůh, že 31. kv[ětna] budu již vidět v tváře svých milých, tak dlouho postrádaných dítek!" Dopis je v soukromém majetku.

40) Rukopis partitury uložen v NM-MAD, inv. č. S 76/1483.

41) NOVÁ, Kateřina - VEJVODOVÁ, Veronika: Nejraději mne tituloval indiánem. Americké vzpomínky na Antonína Dvořáka, Národní muzeum, Praha 2016, s. 47, 60 (dále NOVÁ - VEJVODOVÁ).

42) Viz NOVÁ - VEJVODOVÁ, s. 59-60 (op. cit. v pozn. 41).

43) BURGHAUSER, Jarmil - KUNA, Milan: Antonín Dvořák. IX. symfonie e moll Z Nového světa op. 95. Komentář, in: Antonín Dvořák. IX. symfonie e moll Z Nového světa op. 95. Faksimile, Thomas Music Publishing Prague Edice Muzeum, Praha 2004, s. 12.

44) Deník Kořenského, viz pozn. č. 2. 
„Dále co se paní WEHRLE týče, ta vydržovala u nás v Americe zvaný ,BOARDING HOUSE' (STRÁVNÍ DŮM), 427 kde možno pronajmouti pokoj nábytkem opatřeným, se stravou, ale kam i nepř́slušnici mohou docházeti na stravu. Myslím as podobné,pensionu'v Evropè. Tam Dvoŕákovi docházeli zprvu na obědy i večeře, ale později jenom na obédy. ${ }^{45}$

V Kořenského zápiscích nacházíme záznamy ze tří setkání s Dvořákem - první z druhého dne po př́ijezdu do New Yorku na obědě v boarding housu (1. 6. 1893), druhé setkání po obědě a společná návštěva konzervatoře a třetí den před odjezdem rodiny do Spillville (2. 6. 1893). Kořenský se ocitl v newyorském ubytovacím domě ve společnosti nejen Dvořáka, ale i dalších dvou hudebníků, kteří cestovali přes New York do Chicaga na světovou výstavu - houslisty Karla Ondříčka (1863-1943) ${ }^{46}$ a violoncellisty Artura Krásy (1868-1929). ${ }^{47}$

O Ondříčkově cestě do Ameriky se Dvořákovi dověděli od Josefiny Kounicové

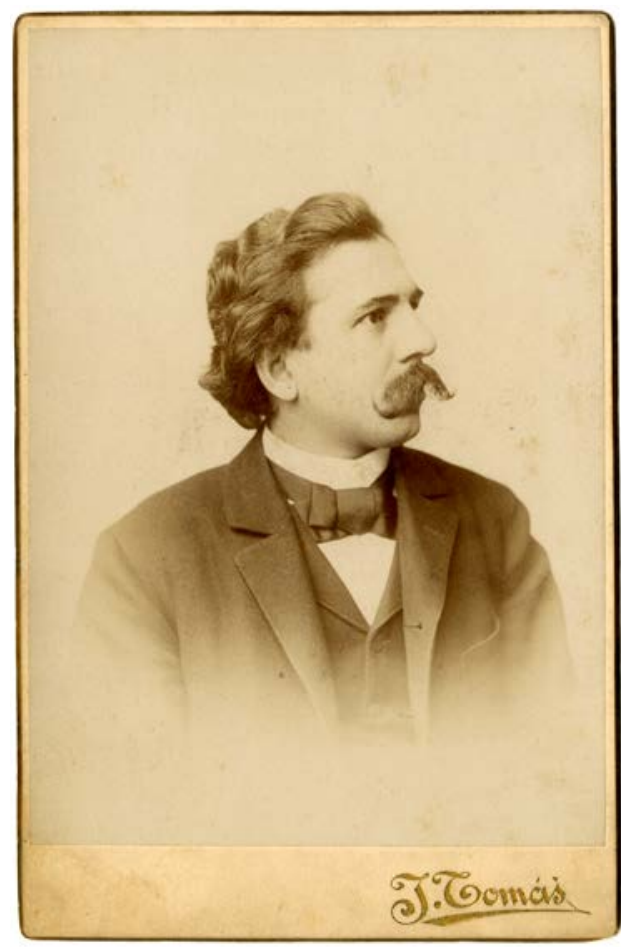

Karel Ondříček (1863-1943)

Photograph, J. Tomáš, Prague, ca. 1892 I

Fotografie, J. Tomáš, Praha, cca 1892

NM-CMH, fond Šich, acquisition no. / č. př. 22/1981 již v lednu 1893: „Také ve včerejších Národních listech byla zpráva, že Karel Ondříček vystoupil ze svazku Národního divadla, neb dostal prý skvělé nabídnutí do Ameriky. ${ }^{48}$ S Ondříčkem se snažila ještě před odjezdem navázat kontakt Klotilda Čermáková, jak o tom píše Terezie Koutecká v dopise Dvořákovým: „P. Ondřička babička vyhledala ten samý den, kdy psaní Vaše přišlo, řekla jí paní, u které bydlel, že právě ten den odcestoval do Ameriky. Byl prý angažován s p. Krásou jistým Berlínským agentem." "99 Podle novinových zpráv přijel Ondříček do New Yorku 4. května, o čemž referoval Pokrok západu: „Dne 4. května prribyl do New Yorku pan Karel Ondřiček, mladši bratr proslaveného, světové pověsti poživajicího českého virtuosa na housle, pana Františka Ondříčk. Pan Ondřiček mladší, který jest taktéž výtečným

45) NOVÁ - VEJVODOVÁ, s. 149 (op. cit. v pozn. 41).

46) ČERNUŠÁK, Gracian: Ondríček, Karel [heslo], in: Československý hudební slovník osob a institucí, 2. sv., M-Ž, Státní hudební vydavatelství, Praha 1965, s. 224.

47) ŠTĚDROŇ, Bohumír: Krása, Artur [heslo], in: Československý hudební slovník osob a institucí, 1. sv., A-L, Státní hudební vydavatelství, Praha 1963, s. 736.

48) Dopis Josefiny Kounicové rodině Antonína Dvořáka, 21. 2. 1893, ADKD 7, s. 39-42. Uloženo v NM-MAD, inv. č. S 76/534.

49) Anna Dvořáková (dcera), Terezie Koutecká Anně Dvořákové, před 1. 5. 1893, uloženo v NM-MAD, inv. č. S 76/1263. 
houslistou a má skvělé vyhlidky do budoucnosti, jest na cestě do Chicaga, kde jest angažován."50 Z dalších novinových zpráv se dovídáme o dobročinném koncertu, který Ondříček s Krásou uspořádali 21. května v newyorském Central Opera House společně s V. Rabochem, českým krajanem, ${ }^{51}$ ve prospěch českého Národního domu v New Yorku (postaven mezi léty 1895 a 1897$).^{52}$

\section{Stereofotograf a všudybyl newyorský Alfred Baštýr}

Z dalších Čechů, kteří obohatili kroužek českých umělců a intelektuálů v New Yorku v době pobytu Antonína Dvořáka a krátké návštěvy Josefa Kořenského, nelze nezmínit Alfreda Baštýře. Dvořák se s „dr. Baštýřem“, ${ }^{53}$ jak je uváděn v pramenech, v New Yorku pravidelně stýkal.

Baštýřovi a Dvořákovi se znali z Prahy - otec Alfreda Moses Baštýř (1835-1894) byl známý pražský stomatolog..$^{54}$ Jeho syn Alfred (1865-1942) studoval stejný obor (studium na lékařské fakultě dokončil v roce 1887). Svou zubařskou praxi v Praze na čas opustil kvůli nabídce ke spolupráci od amerického lékaře v New Yorku. ${ }^{55}$ Podle J. J. Kovaříka zde byl rovněž kvůli konání světové výstavy v Chicagu. ${ }^{56} \mathrm{Z}$ dopisu Terezie Koutecké víme, že Dvořáka několikrát navštívil v newyorském bytě ještě před jejím příjezdem: „Se starým dr. Baštýřm jsem promluvila, vyprávěl mě, že je syn již v Americe, že psal z Nového Yorku, že byl u Vás několikrát př̀ dinner a. t. d. "57 $^{\text {" }}$

Baštýř měl také mnoho zájmů, byl sběratelem, vynálezcem, radioamatérem a později filmovým podnikatelem. ${ }^{58}$ Kromě toho byl vášnivým stereoskopickým fotografem. ${ }^{59}$ Kořenský

50) Češi v Americe, in: Pokrok západu (Omaha, Nebraska), 10. 5. 1893, roč. 22, č. 4, s. 12.

51) O tomto hudebníkovi víme velmi málo. Noviny o něm referují pouze jako o virtuosovi. Viz Dalibor, 27. 2. 1897, roč. 19, č. 15-16, s. 116. Mohlo by se jednat o Václava Rabocha, který účinkoval při otevrení newyorské Carnegie Hall 5. 5. 1891. Viz BINKOWSKI, Carol J.: Opening Carnegie Hall. The Creation and First Performances of America's Premier Concert Stage, McFarland and Company, Jefferson (North Carolina) 2016, s. 117. Kořenský se o něm zmiňuje v zápiscích jako o pianistovi, houslistovi a patrně i jako o skladateli (viz dále přepis zápisků).

52) Týdenní hlasatel přetiskl zprávu z New Yorských Listů. Viz [New Yorské Listy piśí], in: Týdenní hlasatel (Chicago, Ill.), roč. 1, 17. 5. 1893, č. 42, s. 1: „Českému obecenstvu našemu chystá se zase vzácný hudební požitek. Pan Karel Ondříček, znamenitý houslista, první koncertní mistr Národního divadla v Praze a p. Artuš Krása, první koncertní mistr na violoncello u Nár. divadla, uspořádají dne 21 . května velký koncert v Central Opera House na 67 ul. za spoluúčinkování chvalně známého virtuosa prof. V. Rabocha. Tato tři jmena ručí nám za to, že slova ,vzácný prožitek hudební nejsou prázdnou frází. Pánové K. Ondříček a A. Krása, kteří společně do New Yorku přibyli a zde nějaký čas se zdrží, než na další uměleckou pout' po Americe se vydají, jsou umělci $\checkmark$ pravém slova smyslu a nepochybujeme o tom, že koncert jimi uspořádaný v obecenstvu našem vzbudí živý zájem, zvláště podotkneme-li, že třetinu čistého výnosu z koncertu věnují ve prospěch Nár. domu."

53) O něm se také zmiňuje Josef Kovařík v dopisech Otakaru Šourkovi. Viz NOVÁ - VEJVODOVÁ, s. 94, pozn. č. 260 (op. cit. v pozn. 41). Baštýř je zde ale chybně identifikován.

54) TRNKA, Miroslav: Není Baštýŕ jako Baštýř, Rodopisná revue on-line, 2009, roč. 11, č. 2, s. 24. Dostupné z: http://rodopisna-revue-online.tode.cz/2-09_soubory/24-trnka-bastyr.pdf

55) BAŠTÝŘ, Alfréd. Br. Alfred Baštýř (1. prosince 1901). In: HARTL, Antonín: Stavba. Sborník zednářských prací, sv. 2. Hledajicí v temnotách. Vzpomínky nejstarš́ch bratří, J. Thon, Praha 1932, s. 43-52 (dále BAŠTY̌́̌).

56) NOVÁ - VEJVODOVÁ, s. 94 (op. cit. v pozn. 41).

57) Dopis Terezie Koutecké Anně Dvořákové, 14. 5. 1893, uloženo v NM-MAD, inv. č. S 76/1252.

58) Více o sobě Baštýř prozrazuje v citovaném sborníku zednářských vzpomínek, viz BAŠTÝŘ, s. 43 (op. cit. v pozn. 55).

59) MÁDROVÁ, Kamila: Alfred Baštýř (1865-1942). Lékař ve službách nových médií, in: České, slovenské a československé dějiny 20. století, ed. Sylva Sklenářová, roč. 6, Oftis - Gaudeamus, Ústí nad Orlicí - Hradec 


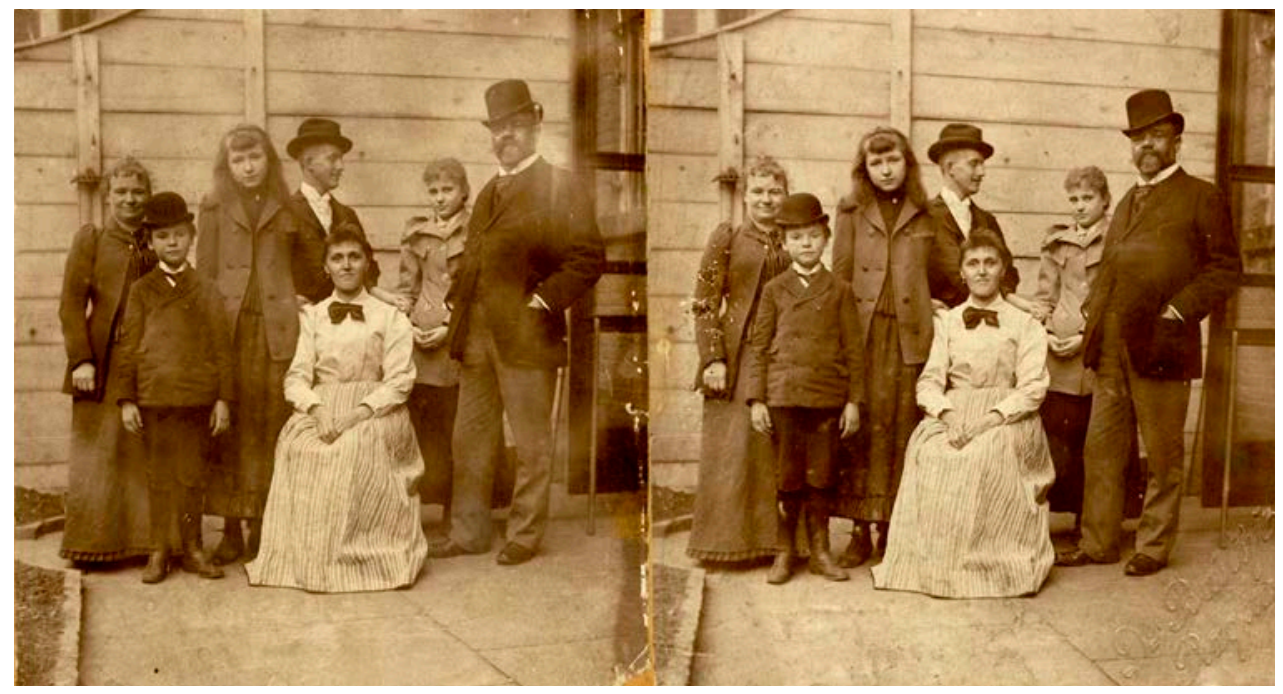

Antonín Dvořák with his family and friends in New York / Antonín Dvořák s rodinou a přáteli v New Yorku Original stereoscopic photograph / Originál stereoskopické fotografie, Alfred Baštýŕr, 1893 NM-ČMH-MAD S 226/1092

v zápiscích a v cestopise na několika místech zmiňuje, že Baštýř v New Yorku fotografoval. Zachytil příjezd lodi s Kořenským a Dvořákovými dětmi: „Po odevzdání zavazadel jsme zase volni jako pták a opouštíme prístaviště za prưvodu doktora Baštýre, jenž tou dobou v New Yorku prodléval a jako pravý všudybyl príchod ,Havoly“ve své fotografické kasetě zachytil."60 Tato fotografie, pokud byla vůbec vyvolána, se bohužel nedochovala. Baštýř vyfotografoval také Kořenského s prráteli na výletě na Conney Illandu. ${ }^{61}$

Baštýř nám naštěstí zanechal dvě stereoskopické fotografie Dvořákovy rodiny pořízené na dvorku domu, ve kterém v New Yorku bydleli. Ty se zachovaly patrně jen díky tomu, že jedna vyvolaná kopie (předpokládám, že byly minimálně dvě) zůstala v New Yorku u Josefa Kovař́ka, který ji v roce 1929 poslal spolu s popisem osob na nich zachycených do Prahy Otakaru Šourkovi: ${ }^{62}$ „Dále nalezl /jsem/ tři skupiny. Označil jsem je I - II - III a napsal jsem na každou jména všech osob. Podobizny tyto vzal Dr. Baštýr z Prahy, jenžzavital do Ameriky $v$ čase výstavy $v$ Chicagu. Lituji, že jiných skupin nemám, ale jsem rád, že se aspoň těchto

Králové, 2011, s. 207-215. Podle dochovaných evidenčních karet v Národním technickém muzeu můžeme soudit, že měl Baštýř v úmyslu zrealizovat soukromý archiv svých stereografických fotografií, viz MÁDROVÁ, Kamila: Baštýŕ Alfred (1. 5. 1865 - 21. 8. 1942) (1911-1938). Inventár. NAD č. 733, evidenční pomůcka č. 283, Národní technické muzeum - Archiv pro dějiny techniky a průmyslu, Praha 2008; MÁDROVÁ, Kamila: Alfred Baštýr (1. 5. 1865 - 21. 8. 1942), stomatolog, filmař, radioamatér, svobodnýzednář, in: Dějiny věd a techniky, roč. 42, 2009, č. 3, s. 205-206. Některé Baštýřovy stereofotografie se dochovaly v Divadelním oddělení Národního muzea (nejstarší česká divadelní fotografie z predstavení hry Imreho Madácha Tragédie člověka v Národním divadle v roce 1892, Národní muzeum - Historické muzeum, inv. č. 32F420, 32F421).

60) KOŘENSKÝ I, s. 42.

61) „Dr. Baštýřr udělal stereoskop. obrázek s príslušnou staffaží.“ Deník J. Kořenského, 3. června 1893, nestránkováno. Viz pozn. č. 2.

62) NOVÁ - VEJVODOVÁ, s. 94 (op. cit. v pozn. 41). 
zachovalo. Mistr se velice nerad nechal fotografovat a tyto obrázky, proti nimž tehdy nijak neprotestoval, vzal Dr. Baštýr a mistr, spokojen, že má zase celou svoji rodinu pohromadè, by snad býval spokojen se nechal fotografovat celý den."

První Baštýřova fotografie byla patrně pořízena ještě před příjezdem dětí s Terezií Kouteckou, protože se na ní nachází pouze manželé Dvořákovi s dcerou Otilkou a synem Antonínem, Josef Kovařík a sestra bytné Dvořákových (paní Siebert, bytná se jmenovala paní Drew) s dcerou (Sadie Siebert). ${ }^{64}$ Druhá fotografie pak byla dle Kovaříka pořízena po příjezdu dětí někdy mezi 31. květnem a 3. červnem, kdy celá Dvořákova rodina odjela do Spillville. ${ }^{65} \mathrm{Na}$ této stereoskopické fotografii se nachází již všichni členové rodiny. ${ }^{66} \mathrm{~V}$ případě třetí fotografie, o které se Kovařík zmiňuje, by se mohlo jednat o fotografii pořízenou na schodech domu v New Yorku opět již se všemi členy rodiny Dvořákových. Tato fotografie však není stereoskopická a dle reprofotografií vyrobených z originálu, ${ }^{67}$ který je neznámý, nelze určit dataci, ani původce fotografie. Z korespondence Terezie Koutecké vyplývá, že i ona se pokoušela patrně tyto fotografie od Baštýře získat, což se jí pravděpodobně nepodařilo. ${ }^{68}$

\section{Přepis útržků ze zápisníku Josefa Kořenského}

Zápisník Josefa Kořenského uložený v Náprstkově muzeu asijských, afrických a amerických kultur v Kořenského pozůstalosti je součástí souboru cestovatelových cestovních deníků a zápisníků z let 1883-1913. Tento z roku 1893 je prvním z řady šesti deníků z cesty kolem světa (č. 1, 2 - Amerika, č. 3 - Amerika, Havaj, Japonsko, č. 4 - Č́na, Malajsko, Jáva, č. 5 Malajsko, Cejlon, Indie, č. 6 - Indie, Egypt).

Zápisník v polokožené vazbě o velikosti $98 \times 151$ mm obsahuje celkem 93 linkovaných listů, strany nejsou číslovány. Deník je popsán od první do poslední strany, nepopsány jsou pouze tři strany v první části a jedna na konci. Obsahuje rukopisné poznámky převážně tužkou, místy perem černé barvy (hlavně na začátku a na konci, kde jsou zapsány adresy jeho kontaktů v Americe). Poznámky tužkou jsou místy doplňovány vpisky červenou a modrou tužkou. Červenou tužku také Kořenský používal k podtrhávání patrně při práci na cestopise, z této doby budou pocházet také barevné poznámky. Slova podtrhaná obyčejnou tužkou si Kořenský zvýraznil zřejmě již během samotného psaní. Deník byl hojně využíván na

63) Tamtéž, s. 94.

64) Uloženo v NM-MAD, inv. č. S 226/1093.

65) Dvořákův českoamerický kalendář se zápisky, uloženo v NM-MAD, inv. č. S 226/884.

66) Kromě nich Sadie Siebert, paní Siebert, paní Drew a soused Dr. Lindemann. Uloženo v NM-MAD, inv. č. S 226/1092.

67) Obě kopie uložené v NM-MAD, inv. č. S 226/1091 a 1801 I1.

68) O Baštýřovi píše Koutecká Dvořákovým již 10. prosince 1894 a informuje je, že si v Praze zařizuje ordinaci a vše „po Americku“. Viz dopis T. Koutecké rodině A. Dvořáka, 11. 12. 1893, uloženo v NM-MAD, inv. č. S 76/1256. Z dopisu také vyplývá, že Dvořákovi k Baštýřovi chodili k zubaři: „Myslí si, že bych tak ráda šla k d. Baštýrí pro ty slíbené fotografie ale nesmím, zapůjčil mi několik amerických písní k opsání, když zde byla paní Štěpánková z Pardubic, přezpívala si je, líbily se jí - a nedala pokoj, až jsem jí je zapůjčila, slíbila mi, že je přeloží a hned zašle - bylo to již včera 14 dní, ona nic neposílá a já nemohu bez nich k Baštýři ani pro fotografie, ani se zubem, který mne již delší čas bolí." Dopis Terezie Koutecké Otilce Dvořákové, 29. 4. 1894, uloženo v NM-MAD, inv. č. S 76/1265. 
cestách, proto jsou Kořenského poznámky velmi špatně čitelné. V deníku se lze orientovat podle dat, kterými jsou nadepsané jednotlivé kapitolky.

Přepsané části byly z deníku vybrány podle relevance a vazby na Antonína Dvořáka a hudební a společenský život v New Yorku. Vynechány byly části, které popisují např. školní systém v New Yorku nebo stavbu mrakodrapů. V deníku se Kořenský Dvořákovi věnuje více než v cestopise, přesto jsou v přepisu odkazy na cestopis, který některé informace uvádí v rozšířené podobě. Datace je v přepisu doplněna dle Kořenského deníku. Přepis je diplomatický, žádné změny v textu nejsou provedeny. Ačkoliv strany nejsou číslovány, čísla stran jsou doplněna dle odpočítání od první popsané strany deníku.

[31. 5. 1893]

[s. 41]

Pošta bude již dávno v N. Y, nežli Havola přibude do Hoboken. ${ }^{69}$ Potom vstoupí lékař a celníci na Havolu. Čekáme mezi citadelami.

Lékař se dostavil, prijal oznámení a bedničku vína a bylo v 2. a 1. po prohlídce. ${ }^{70}$ Přísnější v 3. trídè, kde každý defiloval. ${ }^{71}$

Též celníci prrišli. Posadili se u stolu, a každýz nás oznamoval jméno své, kam jede, jaký občan a kolik má zavazadel a co v nich. Přehlidka ta trvala celkem přes 2 hodiny. ${ }^{72}$

V̌́ecko nalezeno v pořádku. Ve 4 1/4 plujeme dále. Štastni že přijedeme před 6. hod. Před námi kotví vystěhovalecká lod'. Našli tam mezi 2000 lidmi asi 14 nemocných. Bude tu celá meškati v karanténè několik dní.

[s. 42]

O čtvrté hodině v Hoboken. Dvořák v př́stavu s rodinou a dětmi, ježz kytičky nesly svým mladším. Slzy radosti kanuly našemu mistrovi, když zahlédl na palubě své nejmilejší, od nichž dèlilo ho moře téměr již celý rok. Také dr. Baštýr s fotografickou kassetou vítal nově př́chozi a dřvive nás seznal, nežli mi ho uvidèli. Schodiště bylo vytaženo na lod'a nakloněno v bok. Tẽžko bylo sestupovati do celnice za hluku a šumu, jenž nás provázel davem by sám potentát se bližil do NY. Kvètiny házely se na palubu dávno očekávaným známým, mávání šátků s obou stran a hluk a povyk utlumoval všechen hovor. Někteři plakali radostí, jiní se smáli a veselili, že lod’štastně došla břehü. Námořští kolosce ležely tu podél spoutáni. ${ }^{73}$ Také [?]. Sestoupili jsme do celnice: Veliká ratejna.

69) Před připlutím lodi do přístavu přijel k lodi poštovní parník: „Poštovním parníkem přijiždějí také mnozí svým prátelům na ,Havole' vstříc, a poštovní úředník poděluje pasažery novinami, dopisy a telegramy na ,Havolu' adresovanými.“ KOŘENSKÝ I, s. 40.

70) Bednička s vínem byla dárkem od kapitána. KOŘENSKÝ I, s. 40.

71) „Později nežli pošta přijiždí zdravotní lékař, prijímá bedničku, naplněnou rýnským nektarem, jakožto milý dárek od kapitána, přijímá i raport lékaře lodního o zdravotním stavu cestujících prvé a druhé kajuty, a se slovy all right - všecko v pořádku - počíná již přísnější prohlídka mezipalubníků před lékařem defilujících." KOŘENSKÝ I, s. 40.

72) „Konečně dostaví se na ,Havolu' také celníci, zasedají ke stolu a zaznamenávají na zvláštní formuláre naše jméno, občanství, cíl jízdy, počet zavazadel a obsah jejich. Pravdivost svých slov potvrzujeme podpisem místo prísahy." KOŘENSKÝ I, s. 40-41.

73) O setkání s Dvořákem v přístavu se Kořenský v cestopise nezmiňuje. KOŘENSKÝ I, s. 41: „Po mnohých prípravách zarachotila zase kotev ,Havolina', na níž spustil se déšt' vonných kytic a květů, a když přešli jsme za 
[s. 43]

Telegramy (Kabelogramy). ${ }^{74}$

$V$ ní rozestavena jsou písmena začáteční K. R. V. podle toho jak se kdo jmenuje. Tam vynášeji se z lodi všecka zavazadla znamenaná tou kterou písmenou. Listek, který jsme dostali od celníka hned na lodi po vykonané zpovědi, odevzdáme u zvláštního pultu, načež jde s námi celník k zavazadliom a v okamžiku je po prohlídce. Dr. Baštýr vykonal nám tu znamenité služby. Ujal se nás a jako všudybyl New Yorský dovedl nás k ferriboatu ${ }^{75}$ a již pluli jsme jsouce znaveni (zavazadla svěrivše expresovi, aby je do hotelu Belvedere odvezl, kus $50 \mathrm{ct})^{76} z$ Hobokenu do City a potom ele. nazd. železnicí do svého hotelu - v nèm sešli se opèt známí z lodi Havel. První noc v $\underline{B e l v e d e r u}^{77}$ - Večerem dostavili se Krása, Ondř́ćek a malír Procházka, aby nás zavedli do Plzeňské pivnice.

[s. 44]

\section{1. června čtvrtek}

Průvodčím naším byl věrný dr. Baštýr̆, potom p. Weinfurt. Prohlidka činžovních domů. Domovník velšských domů 14 poschod’ových zařizených se všim všudy: (Salony, hovorny, kuřárny atc.) v livreji

Stavby: kostry železné. Nosení cihel a malty na ramenech na zvláštních nositkách. [s. 46]

Přestěhování do boardinghousu

Harry Wehrle

17 E 125

Irving place

N. $Y$.

Viz dále týdně v̌̌e 11 dol.[arů]

V tom boardinghousu obědvá mistr Dvořák s rodinou. Společný lunch. Jidelnou zvaný úzký prostor a zvuky. Bylt to Dvořák s choti, švagr. 6 dètmi, služkou, Kovařikem, my 3 (dr. Vogel),

hlučného ruchu můstek a dotekli se poprvé půdy Nového světa, nebylo objímání ani konce. Přátelé padali si v náruč, radostí se smáli i plakali, a zarosený zrak posvěcoval důvěrné svazky obapolných stran."

74) KOŘENSKÝ I, s. 42: „Ještě zastoupí nám cestu agent telegrafické společnosti kabelové, předkládá nám formulář i ceník, z něhož patrno, že za každé slovo poslané do Prahy platí se 34 centy, a několik minut po tom četli již naši přátelé ve staré Evropě stručný kabelogram: ,Na zdar!"“ O kabelogramech se Kořenský zmiňuje i dřive v knize: „Asi tucet podmořských kabelů položeno jest v hlubinách Atlantického oceanu, a jako nehynoucí památník připomínající světu slavné jméno velikého dobrodince lidstva Morsea, jenž elektromagnetickou silou světy spojil a mrtvé dráty živými nervy učinil.“ KOŘENSKÝ I, s. 26. O kabelogramu se také často zmiňuje Kořenský ve vzpomínkách na Antonína Dvořáka. Viz NOVÁ - VEJVODOVÁ, s. 60 (op. cit. v pozn. 41).

75) Převozní lod', která převážela cestující z prístavu do města.

76) O zavazadlech se Kořenský více rozepisuje: „Vaky odevzdávám ihned komisionáři, jenž se o jejich dopravu do hotelu postará. Veřejných posluhů, jako má např. Praha, za mořem není. Tam nepracuje každý na svůj vrub, ale jest členem společnosti a podniku, jenž za společného působení mnohem jest výnosnější a zprostředkuje dopravu zavazadel a zásilek do celého světa. Tam posluha nechápe se těžkých beden a kufrủ, aby v potu tváři vlekl na svém hřbetě jako soumar po rozlehlém městě, ale ukládá je na povoz účelně zbudovaný a rozváží věci koňmi od hotelu $\mathrm{k}$ hotelu, od domu $\mathrm{k}$ domu. [...] Odměna za donášku počítá se dle kusů a vzdálenosti. Činí obyčejně asi 50 centů za kus." KOŘENSKÝ I, s. 42.

77) Podrobný popis hotelu tamtéž, s. 51-55. 


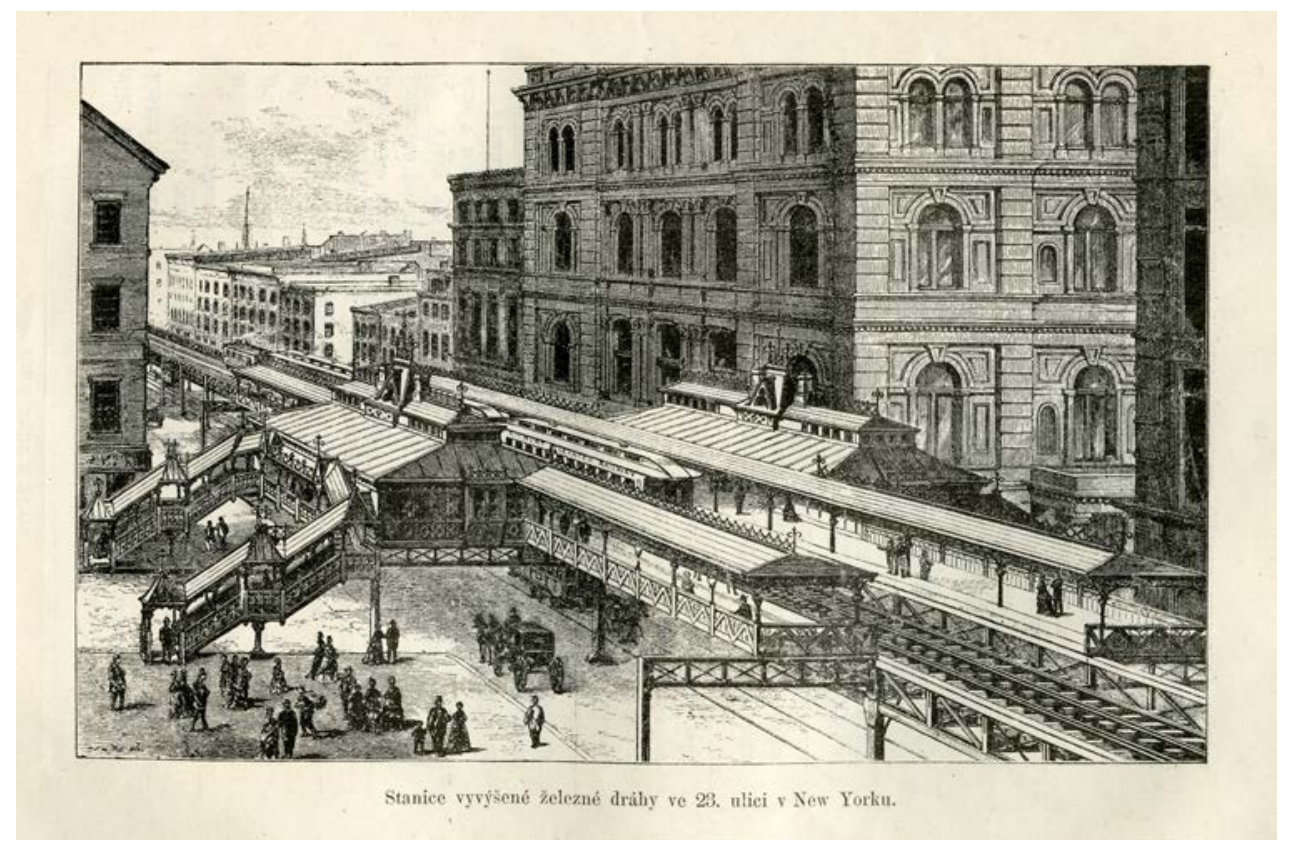

Engraving of New York - elevated train station on $23^{\text {rd }}$ Street / Rytina New Yorku - stanice vyvýšené železniční dráhy ve 23. ulici

Picture from Kořenský's travelogue Journey around the World, Part I, p. 64 / Vyobrazení z Kořenského cestopisu Cesta kolem světa, I. díl, s. 64

dr. Baštýŕ. Umluveno, že tu také my 3 budeme bydleti a se stravovati. Salony velmi útulné a strava s českým knedlikem velmi chutná. K snídani obvyklé lívance (Panecake) jako na lodi. Jsme vzdáleni prílišného hluku. Postele široké - pro dva zároveň. Pokoje se 2 postelemi nejsou. ${ }^{78}$

[s. 47]

Návštèva v konzervatoři hudby. Soukromý diom s menšimi pokojiky. Černoch domovník 126-128 E 17 str. N. Y.

President Mrs. Jeanette M. Thurber.

Dvořák snaži se uvésti černošské motivy v národní hudbu americkou (molové toniny). Prof. jsou placení podle hodin. Board složen z mnohých členů významných mist.

Podobizna Dvořákova v síni. Divadlo ke cvičení sesony. Dramatická škola.

Kovařík pupil teacher. Pocházi ze Spillville Country Winneshiek (u Melwauke), Iowa. ${ }^{79}$ [s. 48]

78) „Drahý Belvedere house zaměnil jsem hned druhého dne za výhodnější pensionát (boarding house) s týdenním platem asi 10 dolarů ( 25 zl.) a při pohostinném stolu našeho mistra Dvořáka připíjeli jsme si na zdraví v Novém světě." Tamtéž, s. 55.

79) $\vee$ cestopise shrnuje svou návštěvu konzervatoře Kořenský takto: „Té doby skončen byl opět školní rok konservatoře, a ředitel její, mistr Dvořák, chystal se na letní pobyt do Spilvillu, české to osady ve státě Iově, vzdálené z New Yorku asi tak, jako je z Prahy na pokraj Sibiře. Musy konservatoře americké tedy na několik měsíců utuchly, a mně bylo dopráno viděti jen prázdné síně skrovného domu, do něhož slavné jméno Dvořákovo přivedlo českého mistra za ředitele." Tamtéž, s. 55. 
[2. 6. 1893]

Kobědu (lunchu) s Dvořákem. Loučení. Odjiždi zitra do Spillvillu, do české osady.

[s. 65]

[5. 6. 1893$]^{80}$

Večer do koncertu Seidlova. Na programu Liszt, Mascagni, Grieg, Wagner, Dvorak (Dances Bohemia). ${ }^{81}$

[s. 73$]$

[8. 6. 1893]

Plat za týden u Wehrle s pivem a všim 11 dolarů.

Návštěva u Rabocha. Co Čech, to hudebník opèt se tu osvědčilo. Praeludia, fugy, koncerty na piano a solo housle.

\section{Závěr}

Kořenský měl možnost setkávat se s Dvořákem v New Yorku během tří dnů od 31. května do 2. června 1893. I když se oba znali z pražských intelektuálních kruhů, jejich rozhovory nebyly příliš obsáhlé. Podle Kořenského skladatel příliš nemluvil. Setkání s Dvořákem shrnul s odstupem čtyřiceti let v dopise Otakaru Šourkovi:

\section{„Vážený pane!}

Ve své Cestě kolem světa (I. díl, str. 55) zmiňuji se na jedné stránce také o Dvořákovi. Knihu tu má Čes. mus., Náprstk. čitárna (Betlemské nám), Univers. Knih. V květnu 1893 plul jsem z Brém na lodi, kterou se plavila do New Yorku také rodina Dvořákova. Jela za Dvoŕákem, kterýjel už dřive do Ameriky. Parník byl obsazen a pí. Dvoř. byla ráda, že dostala místo ve 2. třídè. Proto jsem ji z 1. tř́dy navštèvoval. Když jsme přistáli k amer. břehưm, čekal na parník Dvořák. Vidèli jsme ho z paluby a zasypávali jsme ho květy. VNew Y. jsme žili společně v pensionátě. Dvořák mluvíval málo, jak známo, ale do své konservatoře mè prece zavedl. Byl to ústav skrovný, založený jeho ctitelkou.

Povede-li Vás cesta Smíchovem, zastavte se na Arbesově náměstí čís. 70. Bydlím ve 2. posch. okresního domu. Bývám doma od 10-11 a od 3-4.

Na shledanou

Váš ochotný

Josef Kořenský

Na Smíchově 23. řijna 34:

80) Poslední den, kdy se Dvořák mohl s Kořenským setkat, bylo 4. 6., jelikož 5. 6. Dvořákovi odcestovali do Spillville. Na tomto koncertě tedy již nemohl být Dvořák př́tomen. Kořenský definitivně opustil New York 15. 6. 1893. Viz TODOROVOVÁ - CHOVANEČEK, s. 24 (op. cit. v pozn. 7).

81) Kořenský navštívil jeden z populárních koncertů, které dirigoval Anton Seidl. Viz A Series of Seidl Concerts. The Sun, 4. 6. 1893, roč. 60, č. 277, s. 10: „Madison Square Garden To-Morrow, Monday evening, June 5, at 8:15, summer opening of the Annual Promenade Concerts by ANTON SEIDL and his great Metropolitan Orcheatra. Soloists: Mr. Viktor Herbert, Mr. A. Seifferth". Na koncertě patrně zazněly Dvořákovy Slovanské tance, a to bud' 1. řada (op. 46, B83), nebo 2. řada (op. 72, B147).

82) Dopis J. Kořenského O. Šourkovi, viz pozn. 1. 
Dvořák mohl v New Yorku Kořenského informovat o svém pobytu v New Yorku a o svém působení na konzervatoři v pozici ředitele.$^{83} \mathrm{I}$ když nám cestovatel zachoval pouze skrovné svědectví o svých setkáních s Dvořákem, jeho zápisky i cestopis detailně dokumentují nejen samotnou cestu a město New York v roce 1893, ale také dokládají styky českých hudebníků a intelektuálů, kteří se v té době za mořem setkali. Dvořákův newyorský pobyt tak díky informacím od Kořenského nabývá na plasticitě a autentičnosti.

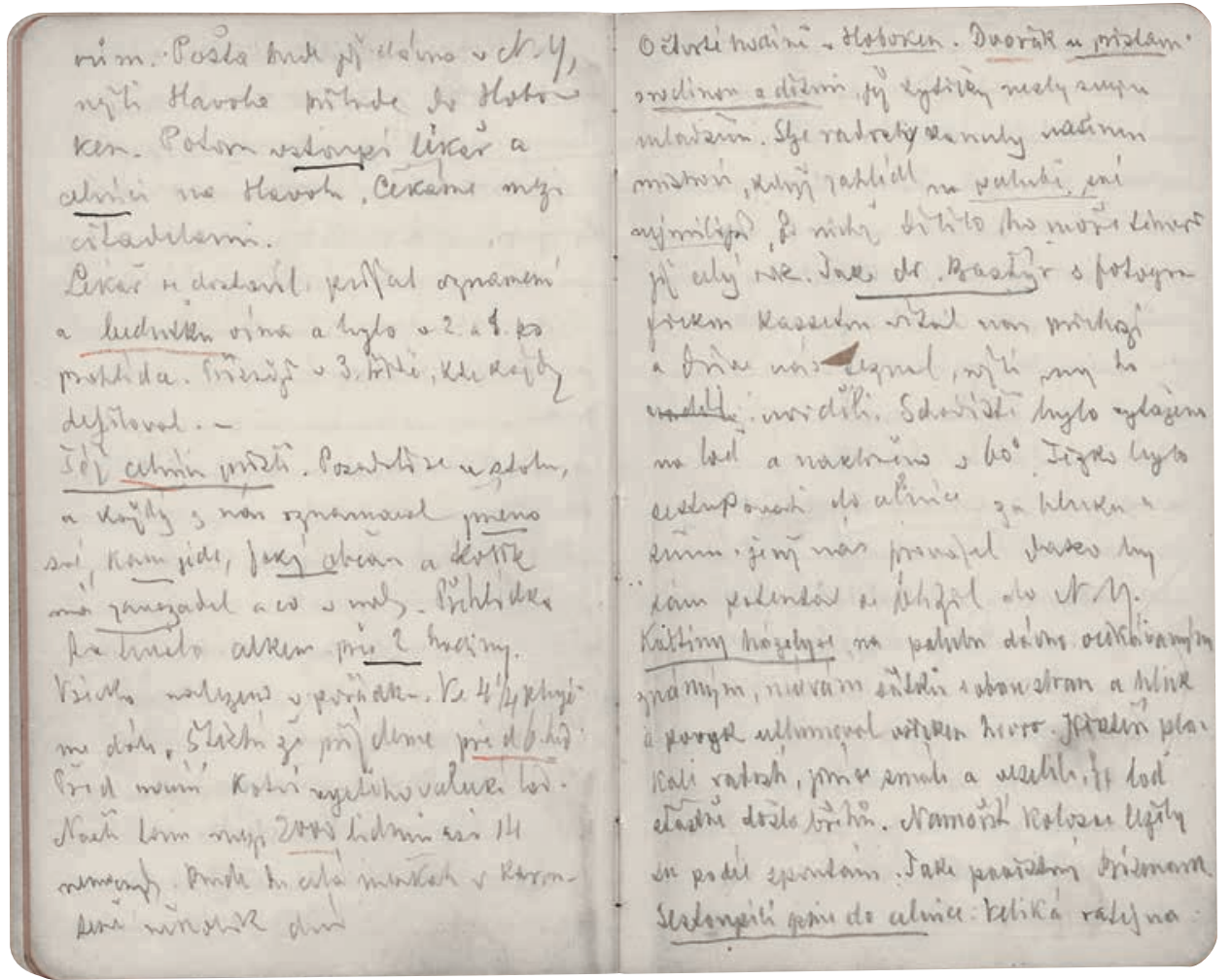

Josef Kořenský’s diary / Deník Josefa Kořenského

NM-NpM, Sbírkové oddělení-Archiv, Kořenský 3/33

Adresa: Veronika Vejvodová, Muzeum Antonína Dvořáka, Ke Karlovu 20, 12000 Praha 2, Česká republika

E-mail:veronika_vejvodova@nm.cz

83) Vyplývá to z informací, které Kořenský uvádí v cestopise. Zajímavá je zmínka o Dvořákově platu na konzervatoři: „Jak Amerika dovede odměňovati osoby, kteréž podnikům mají dodati lesku a slávy, vysvítá z toho, že Dvořákovi platí se ročně za řízení konservatoře dvakrát tolik, co má za své služby správce celého království Českého". Viz KOŘENSKÝ I, s. 56. 